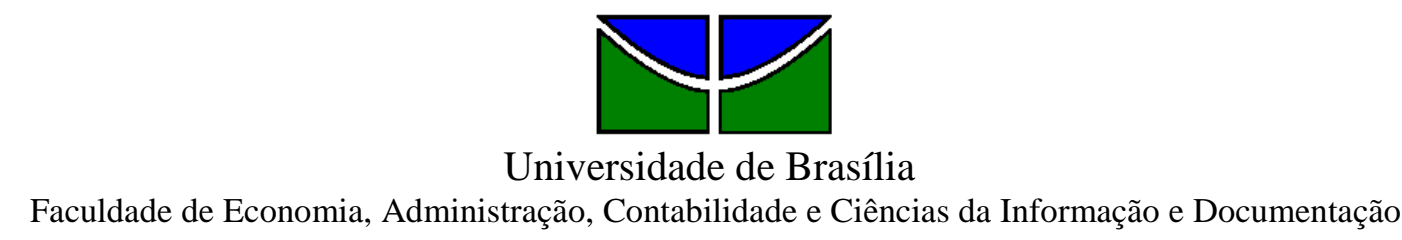

DEPARTAMENTO DE ADMINISTRAÇÃO

TRABALHO DE CONCLUSÃO DE CURSO

\title{
SUPERAÇÃO DE OBSTÁCULOS E INOVAÇÃO: Estudo de Caso da Fazenda Malunga
}

\section{Juliana Gomes Madureira}




\title{
SUPERAÇÃO DE OBSTÁCULOS E INOVAÇÃO: Estudo de Caso da Fazenda Malunga
}

\author{
Juliana Gomes Madureira
}

Professor Orientador:

\section{Dr. José Márcio Carvalho}

"Trabalho apresentado em cumprimento às exigências acadêmicas parciais da disciplina Estágio Supervisionado em administração para a obtenção do grau de Administradora" 
Madureira, Juliana Gomes

Superação de Obstáculos e Inovação: Estudo de Caso da Fazenda Malunga / Juliana Gomes Madureira. - 2009.

77f. : il

Monografia (graduação) - Universidade de Brasília, Departamento de Administração, 2009.

Orientação: Prof. Dr. José Márcio Carvalho, Departamento de Administração.

1. Gestão Estratégica. 2. Inovação. 3. Agronegócio 


\title{
SUPERAÇÃO DE OBSTÁCULOS E INOVAÇÃO: Estudo de Caso da Fazenda Malunga
}

\begin{abstract}
A Comissão Examinadora, abaixo identificada, aprova o Trabalho de Conclusão do Curso de Administração da Universidade de Brasília da aluna
\end{abstract}

\section{Juliana Gomes Madureira}

José Márcio Carvalho, Dr.

Professor-Orientador

Domingos Spezia, Msc.

Coordenador de Estágio Supervisionado
Olinda Maria Gomes Lesses, Msc.

Professora-Examinadora 


\section{Dedicatória}

Dedico este trabalho, especialmente, às pessoas mais importantes da minha vida: meus pais, meus dois irmãos e meu marido. Dedico também a todas as pessoas que me acompanharam nessa jornada. 


\section{Agradecimentos}

Agradeço, primeiramente, a Deus, pela vida.

Agradeço a meus pais, Laercio e Dulce, pelos muitos ensinamentos, pelo exemplo de vida e pelo amor incondicional.

Agradeço aos meus irmãos, Daniela e Fabiano, meu cunhado Júlio e meu sobrinho Gustavo, por todos os momentos que passamos juntos, que foram e são muito especiais para mim.

Agradeço ao meu "namorido" Fábio, por me amar de uma forma que eu não imaginava merecer e me ajudar a ser alguém melhor a cada dia. Agradeço também à minha sogra, D. Antônia, por ser minha segunda mãe.

Agradeço ao meu orientador José Márcio, pela disponibilidade, presteza, atenção e por disseminar o conhecimento com tanta sabedoria.

Agradeço aos funcionários da Fazenda Malunga, sempre dispostos e amáveis e, em especial, à Clevane, que me fez perceber que o sucesso depende de muito trabalho, mas também de muito amor pelo que se faz.

Agradeço, por fim, a todos que estiveram comigo durante esta jornada. 


\section{RESUMO}

O presente trabalho, apresentado sob a forma de estudo de caso único, teve como objeto a empresa Fazenda Malunga, localizada no Distrito Federal e especializada em produção agropecuária de produtos orgânicos. Os objetivos principais da pesquisa foram: conhecer a trajetória da empresa e as principais dificuldades encontradas nos processos de produção agrícola, processamento pós-colheita, comercialização e gestão, além de descobrir de que forma a implementação de inovações (de produtos, processo, técnicas de gestão, formas de comercialização, dentre outros) pode ter ajudado na superação dessas dificuldades. A relevância do trabalho é justificada, principalmente, pela posição de destaque ocupada pela empresa no Distrito Federal, além do potencial de crescimento do setor de Agronegócios, notadamente de produção de produtos orgânicos na região. Para atingir os objetivos propostos, buscou-se, primeiramente, na literatura, o embasamento teórico para o trabalho, principalmente voltado aos construtos de Estratégia e Inovação, além de publicações a respeito do setor investigado, qual seja, o Agronegócio, bem como a produção orgânica de alimentos. A coleta de dados foi feita a partir de visitas a campo, com utilização de observação direta e entrevistas, além de pesquisa a dados secundários, como, por exemplo, publicações a respeito da empresa pelo SEBRAE-DF, publicações estas que classificaram a empresa estudada como a maior produtora de orgânicos do Distrito Federal. Os dados coletados foram analisados e organizados, resultando num relato que permite conhecer um pouco mais sobre o histórico e a realidade atual da empresa, além da oportunidade de verificar que as inovações implementadas nas áreas de produção, processamento pós-colheita, comercialização e gestão, devem ser consideradas como relevantes na trajetória em busca do crescimento sustentável da organização. 


\section{SUMÁRIO}

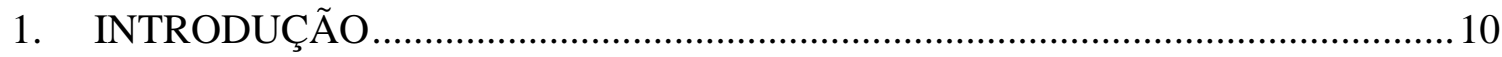

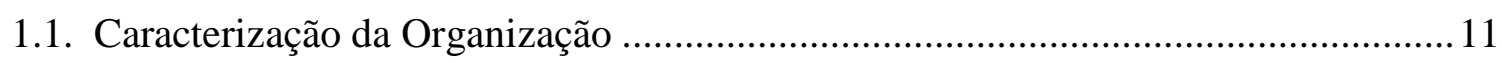

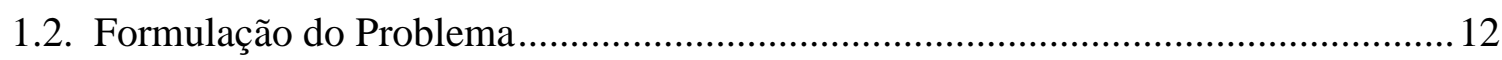

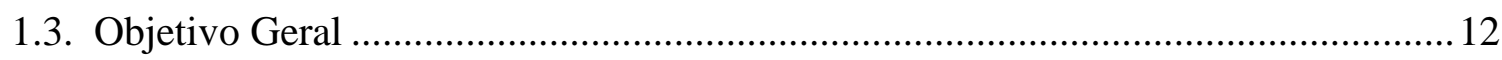

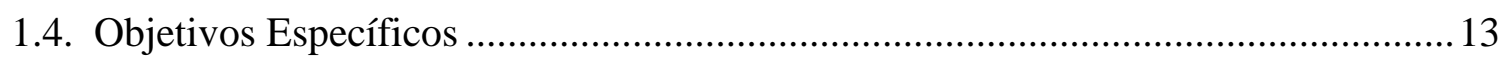

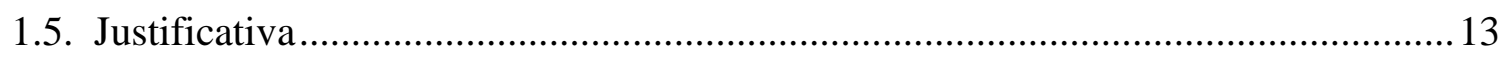

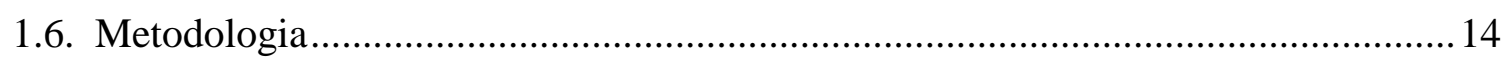

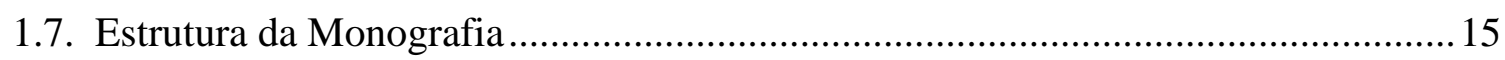

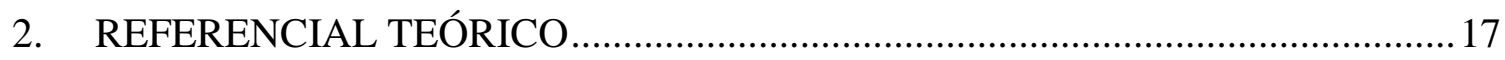

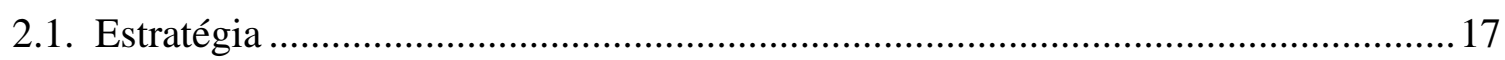

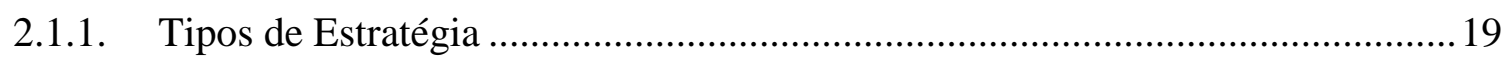

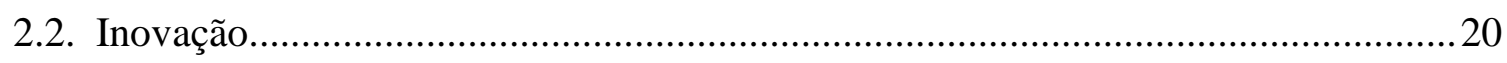

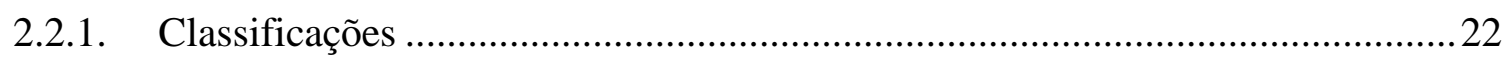

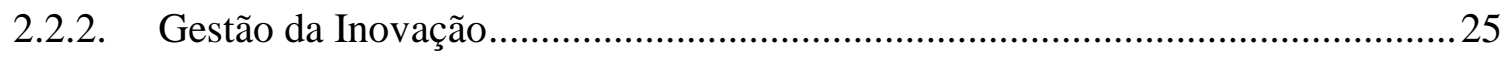

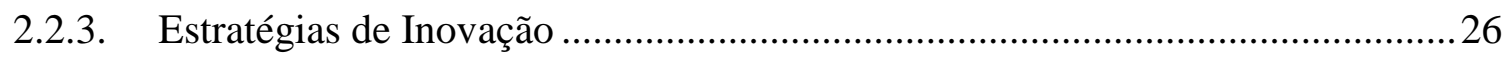

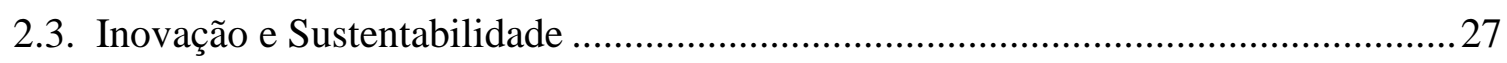

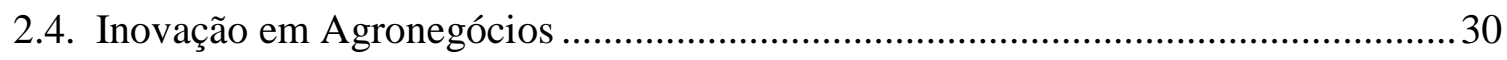

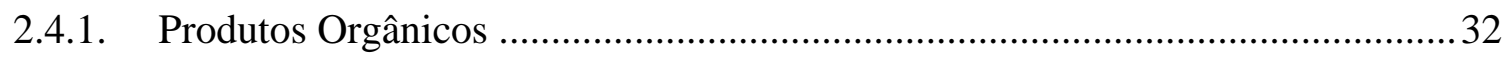

2.4.2. Produtos Minimamente Processados ................................................................... 34

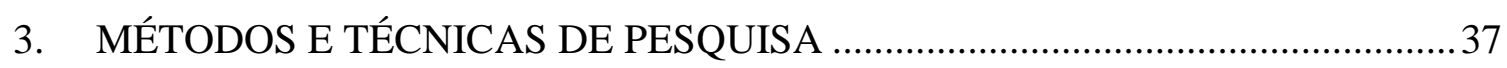

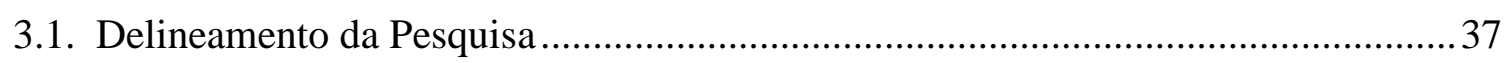

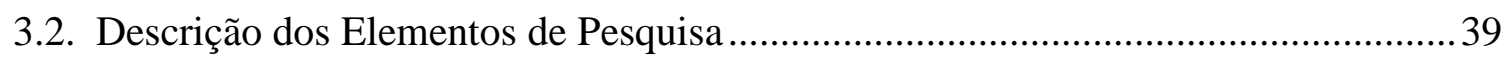

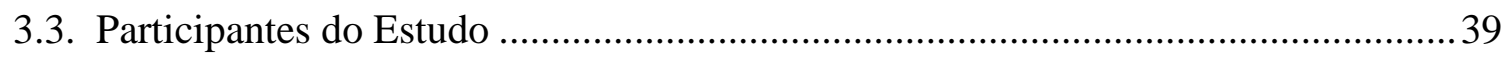

3.4. Procedimentos e Instrumentos Utilizados na Coleta e Análise dos Dados ...............40

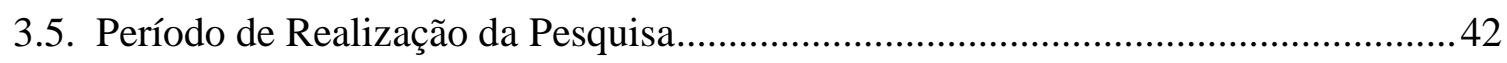

3.6. Comentários Sobre o Processo da Coleta de Dados ....................................................42

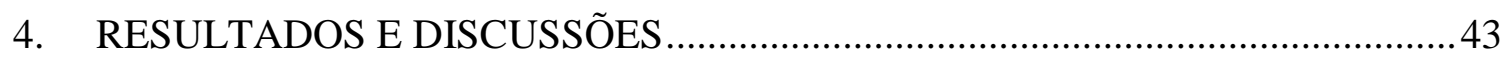

4.1. Superação de Obstáculos e Inovações na Produção Agrícola .......................................43

4.1.1. Uso de Indicadores para a Análise da Gestão do Produto......................................46

4.1.2. Implementação de Melhorias na Produção em Quatro Etapas ..............................47

4.1.3. Estudos Relacionados à Necessidade Nutricional de Cada Espécie.....................50

4.1.4. Fabricação de Insumo Próprio …………………………………………….......

4.1.5. Dificuldades Relacionadas à Produção Agrícola Atual.........................................52

4.2. Superação de Obstáculos e Inovações no Processamento Pós-Colheita ....................54 
4.2.1. Produtos Minimamente Processados: Agregação de Valor..................................54

4.3. Superação de Obstáculos e Inovações na Comercialização .......................................56

4.3.1. Contratação de Promotores para Atuação em Supermercados .............................58

4.3.2. Aperfeiçoamento das Visitas Guiadas .............................................................59

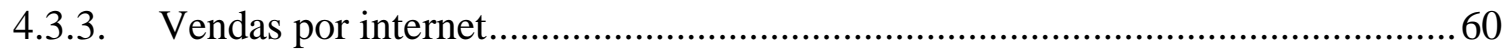

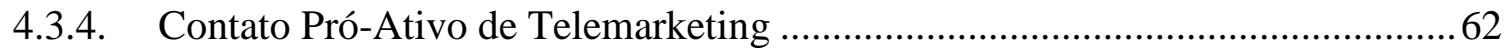

4.3.5. Compra de Caminhão e Organização da Logística de Distribuição....................62

4.3.6. Dificuldades Relacionadas à Comercialização Atualmente ...............................63

4.4. Superação de Obstáculos e Inovações na Gestão Integrada da Empresa ..................64

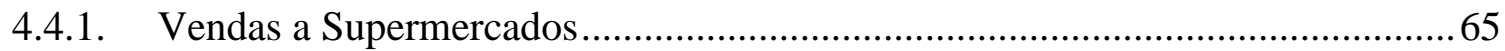

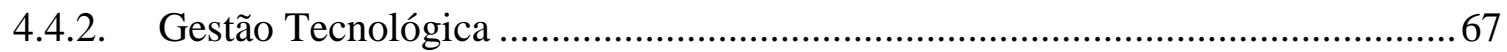

4.4.3. Conselho de Gestão e Políticas de Remuneração ..................................................67

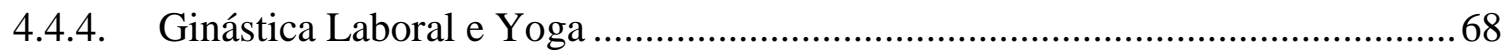

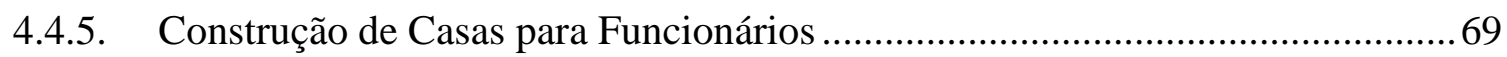

4.4.6. Definição e Formalização do Planejamento Estratégico ....................................69

4.4.7. Dificuldades Relacionadas à Gestão Atualmente............................................. 70

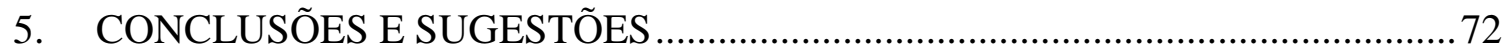

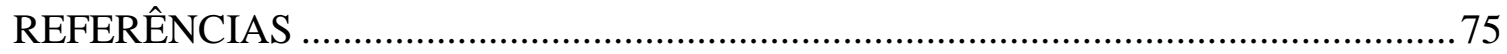




\section{LISTA DE FIGURAS}

Figura 2.1 - Uma tipologia de inovações sustentáveis.......................................................28

Figura 4.1 - Uso do plástico na cobertura do solo na Fazenda Malunga.................................48

Figura 4.2 - Fabricação de biofertilizantes na Fazenda Malunga...........................................51

Figura 4.3 - Pátio de compostagem da Fazenda Malunga....................................................52

Figura 4.4 - Produtos de outros estados brasileiros garante fornecimento regular..................53

Figura 4.5 - Produtos minimamente processados: Alface Americana Orgânica Higienizada e

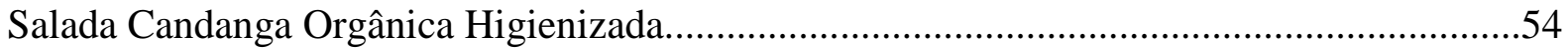

Figura 4.6 - Visita à Fazenda Malunga em 24/05/2009...................................................59

Figura 4.7 - Página inicial do sítio da empresa Fazenda Malunga na internet.........................60

Figura 4.8 - Confirmação de compra por e-mail..............................................................61

Figura 4.9 - Ginástica Laboral realizada na Fazenda Malunga em 04 jun 2009.....................68 


\section{LISTA DE QUADROS}

Quadro 1.1 - Quadro-resumo dos métodos e técnicas de pesquisa utilizados.........................15

Quadro 4.1 - Superação de obstáculos em produção agrícola pela Fazenda Malunga.............44

Quadro 4.2 - Principais dificuldades em produção atualmente e possíveis soluções...............52

Quadro 4.3 - Superação de obstáculos em comercialização pela Fazenda Malunga...............57

Quadro 4.4 - Principais dificuldades encontradas em comercialização atualmente.................63

Quadro 4.5 - Superação de obstáculos em gestão pela Fazenda Malunga...............................64

Quadro 4.6 - Principais dificuldades encontradas em gestão atualmente...............................70 


\section{INTRODUÇÃO}

A busca pelo crescimento, ou mesmo pela sobrevivência no mercado em acelerada transformação, tem indicado às organizações que o esforço pela implementação de inovações pode ser um diferencial competitivo decisivo.

No entanto, esse processo de geração e implementação de novos conhecimentos, ainda que de forma incremental e técnica, parece não ser algo tão natural e simples de ser concretizado pelas organizações. Pelo contrário, a inovação é objeto de muitos estudos, quer seja por administradores, economistas ou outros acadêmicos, pois trata de assunto complexo, em que há significativo risco, obstáculos ou dificultadores a serem superados e cuja gestão deve ser feita de maneira eficiente e estratégica para aumentar as chances de êxito.

Nesse contexto, o presente trabalho tem como objetivo apresentar a empresa Fazenda Malunga, enquanto um caso a ser analisado, por ser uma empresa que se destaca pela busca e implementação de inovações, seja em produtos, processos ou outros aspectos tidos como responsáveis, dentre outros diferenciais, por imprimir à empresa atualmente o título de maior produtora de verduras orgânicas do Distrito Federal (SEBRAE, 2008).

Conforme pode ser visto na revisão da literatura sobre estratégia, inovação e agronegócios, em contraste com a produção convencional de alimentos, a produção de produtos orgânicos, livres de agrotóxicos e fertilizantes químicos, tem se mostrado um diferencial inovador. Essa prática agrega valor ao mercado de alimentos, cuja demanda tem aumentado muito nos últimos anos, principalmente, dentre os consumidores preocupados com a própria saúde e/ou imbuídos de ideais de sustentabilidade.

Porém, a produção e comercialização de produtos orgânicos, segundo diversos autores, traz dificuldades à empresa, inerentes, por exemplo, à mudança de cultura do consumidor, acostumado aos preços do produto convencional, já que terá de pagar um maior valor pelo produto livre de agrotóxicos. Além disso, o produtor de produtos orgânicos precisa enfrentar todas as outras dificuldades inerentes à agricultura convencional, tais como, clima, qualidade do solo, disponibilidade e capacitação de mão-de-obra, acesso a crédito, distância de mercados consumidores, dentre outros. 


\subsection{Caracterização da Organização}

A empresa Fazenda Malunga, conforme dados encontrados em seu sítio na internet, bem como em outras publicações como a revista Conhecer SEBRAE (2008) e Casos de Sucesso SEBRAE (2007), foi criada em 1983 e está localizada na Colônia Agrícola Lamarão, Ch. 16, no PAD-DF, em uma área de 110 hectares a 70 quilômetros da cidade de Brasília.

Suas principais atividades são a olericultura, a avicultura, a produção de derivados de leite e a fruticultura, tendo como principal diferencial a Agricultura Orgânica, ou produção agroecológica, sem o uso de insumos químicos. A empresa se destaca no cenário de Agronegócios como a principal produtora de Orgânicos do Distrito Federal, tendo recebido, em 2005, o Prêmio Êxito Empresarial, oferecido pelo SEBRAE-DF.

Sua produção é certificada por entidades nacionais e internacionais que fiscalizam periodicamente a produção, autorizando o uso do selo de qualidade orgânica aos seus produtos.

A empresa tem como missão: "Proporcionar qualidade de vida por meio da produção de alimentos orgânicos, educação ambiental e desenvolvimento de tecnologias limpas, respeitando o meio-ambiente, os colaboradores e consumidores, de forma competitiva."

Sua visão é "Consolidar-se como uma marca líder em produção de alimentos orgânicos, associada à qualidade de vida, por meio de uma gestão eficiente, utilizando-se de tecnologias limpas e equipes capacitadas como diferencial competitivo, comprometidos com a qualidade total e a satisfação dos consumidores e colaboradores".

A empresa tem como valores: qualidade de vida, respeito ao meio-ambiente e pessoas, responsabilidade social, honestidade, eficiência, competitividade.

Nos últimos seis anos, a empresa, que tem uma produção mensal de 200 toneladas, dentre hortaliças (folhosas), legumes, leite e derivados, apresentou crescimento médio de $25 \%$, sem qualquer financiamento de bancos oficiais ou privados, sendo que sua receita em 2007 alcançou a cifra de quatro milhões de reais.

Seus produtos são fornecidos para supermercados das redes Pão de Açúcar, Carrefour, Big Box e Wall Mart. A empresa possui marca própria, mas também vende seus produtos com bandeiras de alguns clientes varejistas, como Taeq (marca Pão de Açúcar) e Viver (marca Carrefour). Possui também o serviço de entregas diretas em residências, cujos 
pedidos podem ser feitos por telefone ou mesmo pela Internet, e também oferece seus produtos diretamente em feiras e lojas de produtos naturais.

Sua equipe de funcionários conta hoje com 170 pessoas e sua política de gestão inclui a distribuição de $30 \%$ de seus lucros a seus funcionários, bem como o oferecimento constante de treinamentos, e atividades como orientação com fisioterapeutas e ginástica laboral. Além disso, cada funcionário, ao completar oito anos de casa, adquire o direito de integrar o Conselho de Gestão da Malunga.

A empresa possui, em seu sítio na internet, uma área destinada àqueles que pretendam conhecer a Fazenda Malunga. Para isso, no ano de 2008, a empresa construiu em suas instalações um restaurante que fornece alimentação diária a alguns de seus funcionários e é também utilizado para o fornecimento de alimentação às cerca de 1.200 pessoas que visitam a empresa durante o ano.

\subsection{Formulação do Problema}

Após as considerações anteriores, pode-se definir que o problema de pesquisa é o seguinte:

- Quais foram os principais obstáculos enfrentados pela Fazenda Malunga na condução de seu negócio e como a implementação de inovações ajudou a superá-los?

\subsection{Objetivo Geral}

O trabalho buscará identificar e analisar as dificuldades encontradas no processo de condução do negócio da empresa Fazenda Malunga, como foram superadas e de que forma a implementação de inovações ajudou nesse processo. 


\subsection{Objetivos Específicos}

Os objetivos específicos da presente estudo de caso são:

- Identificar e analisar as dificuldades encontradas nos processos de gestão, comercialização, produção agrícola e processamento pós-colheita.

- Conhecer a trajetória de inovações da organização.

- Conhecer o impacto causado pelas inovações no crescimento da empresa.

- Conhecer a postura estratégica da empresa.

- Conhecer que técnicas de gestão, relacionadas a finanças, recursos humanos, marketing, dentre outras, são aplicadas na administração do empreendimento.

\subsection{Justificativa}

O produtor rural, de uma forma geral, é normalmente considerado um empreendedor de espírito mais tradicional, apegado às suas raízes, avesso a novos riscos, além daqueles aos quais é habituado (ou obrigado a conviver), como a sazonalidade da produção devido às variações climáticas, por exemplo.

No entanto, existem sinais de mudança na postura desse produtor rural que percebe a necessidade de aprimorar não apenas os aspectos técnicos de seu negócio, como também administrar estrategicamente, adotando modernas e eficazes técnicas de gestão na busca por maiores diferenciais competitivos e na superação de dificuldades inerentes à gestão de uma empresa rural.

A competitividade acirrada e a disputa por novos mercados levam o produtor rural a modernizar sua produção e buscar novas oportunidades de mercado, como, por exemplo, o mercado de produtos orgânicos, o que hoje é considerado um fator de ganho de uma fatia de mercado em crescimento. 
Nesse sentido, estudar uma empresa inovadora é oportuno, principalmente por se tratar da maior produtora de orgânicos do Distrito Federal (SEBRAE, 2008), com crescimento médio de $25 \%$ ao ano, nos últimos seis anos.

Outro aspecto a ser considerado é o potencial de entrada de novas empresas nesse mercado, em que se observa, conforme estudos realizados pela EMATER-DF, em Pesquisa de Diagnóstico do Consumo de Produtos Orgânicos no Distrito Federal realizada em 2005, que existe a necessidade de que a produção de orgânicos no DF seja aumentada e diversificada, a fim que a demanda por esses produtos seja atendida na região.

É importante enfatizar ainda o fato de que a empresa investe, conforme publicações do SEBRAE (2008), constantemente em inovação, seja em novas formas de produção, como a inclusão de produtos minimamente processados, saladas orgânicas higienizadas e prontas para o consumo, seja em marketing, como a venda de produtos por internet, cuja entrega é feita em domicílio.

Ainda com o objetivo de fomento ao mercado de produtos orgânicos da região do Distrito Federal, conhecer de perto as dificuldades encontradas por uma empresa de destaque desse setor, e apresentar as ações ou inovações implementadas por essa empresa para a superação dessas dificuldades, pode ter como resultado um conhecimento que poderá vir a corroborar, sob a forma de Benchmarking, para os novos entrantes do setor, ou mesmo para aquelas empresas que lutam por se estabelecer ou crescer nesse mercado.

\subsection{Metodologia}

A fim de corroborar com a consecução dos objetivos do trabalho, primeiramente, buscou-se na literatura disponível a respeito de estratégia e inovação a base teórica necessária ao entendimento do que se pretendia observar e aprender ao final do estudo de caso.

Além disso, a base teórica sobre esses temas, aliada a uma revisão bibliográfica sobre Agronegócio é útil não apenas para buscar respostas aos fenômenos que se pretendia observar, mas primeiramente, para servir como referencial para o desenvolvimento das questões mais objetivas e perspicazes, levadas a campo.

Nesse sentido, tem-se que o principal instrumento de coleta utilizado no estudo de caso em questão foi a entrevista semi-estruturada. Além da entrevista, foram analisados dados 
secundários a respeito da empresa, como publicações do SEBRAE-DF, além de informações obtidas em visitas à empresa, por meio da observação direta.

Segue abaixo um quadro-resumo dos principais métodos utilizados na condução da presente pesquisa:

\begin{tabular}{|c|c|}
\hline Quanto aos níveis de pesquisa & $\begin{array}{l}\text { - Pesquisa Descritiva } \\
\text { • Estudo de caso único }\end{array}$ \\
\hline Quanto à utilização dos resultados & - Pesquisa Fundamental \\
\hline Quanto aos procedimentos de coleta & $\begin{array}{l}\text { - Pesquisa bibliográfica } \\
\text { - Pesquisa documental } \\
\text { - Pesquisa de campo } \\
\text { - Estudo de caso }\end{array}$ \\
\hline Quanto à modalidade de aplicação & $\begin{array}{l}\text { - Pesquisa Qualitativa } \\
\text { - Entrevista semi-estruturada } \\
\text { - Observação direta }\end{array}$ \\
\hline
\end{tabular}

Quadro 1.1 - Quadro-resumo dos métodos e técnicas de pesquisa utilizados

Fonte: elaborado pela autora, junho de 2009.

No capítulo dedicado aos Métodos e Técnicas de Pesquisa, as escolhas metodológicas resumidas no Quadro 1.1 serão mais bem detalhados e embasados na literatura sobre o tema.

\subsection{Estrutura da Monografia}

O presente estudo de caso está dividido em cinco capítulos. O primeiro deles, introdutório, objetiva fazer uma breve contextualização e inicialização aos assuntos que são conhecidos com a leitura integral da pesquisa. A empresa é caracterizada, bem como seu ambiente. São também abordadas questões relacionadas ao porquê da escolha do tema (justificativa), e os objetivos que se deseja alcançar com a finalização do trabalho.

A segunda parte se destina a apresentar conceitos que servem como base teórica a embasar toda a pesquisa, ou seja, a revisão da literatura relacionada aos assuntos inerentes ao trabalho. São abordados os conceitos de estratégia, tipos de estratégia, inovação, suas classificações, sua gestão, estratégias de inovação, bem como conceitos mais relacionados ao setor em que a empresa estudada está inserida, qual seja, o Agronegócio. Itens como inovação 
em agronegócios, e aspectos relacionados à produção orgânica e produtos minimamente processados são brevemente apresentados ao leitor.

O terceiro capítulo se presta ao delineamento da pesquisa, como foi metodologicamente embasada a coleta dos dados e a forma como os dados são analisados.

O quarto capítulo apresenta os resultados da ida a campo e sugere algumas discussões possíveis acerca do problema de pesquisa.

O quinto e último capítulo apresenta as conclusões, propostas e sugestões acerca do trabalho. 


\section{REFERENCIAL TEÓRICO}

Este capítulo é se presta a apresentar os principais construtos teóricos que embasaram e nortearam a presente pesquisa, bem como foram, de certa forma, colocados a prova quando relacionados a um caso real, prático; não no sentido da validade da teoria em si, mas no quanto esta se alinha ou é colocada em prática pela empresa estudada.

A revisão da literatura, antes mesmo da ida a campo, mostrou-se de grande importância para o melhor entendimento dos fenômenos a serem escolhidos para análise.

Primeiramente são apresentadas teorias retiradas da literatura existente sobre Estratégia, alguns de seus conceitos e tipos.

A seguir, são trazidas à tona idéias a respeito do construto Inovação, seus conceitos, tipos, gestão e estratégias.

São abordadas noções sobre Inovação e Sustentabilidade e Inovação em Agronegócios, temas diretamente relacionados ao trabalho. São também abordados os conceitos de Produtos Orgânicos e Produtos Minimamente Processados, a fim de que o leitor esteja mais familiarizado com esses produtos quando da leitura dos resultados da pesquisa.

\subsection{Estratégia}

O significado literal da palavra estratégia é "a arte do general", e sua origem está relacionada a forças militares para derrotar o inimigo. Numa empresa, a estratégia "está relacionada à arte de utilizar, adequadamente, os recursos físicos, financeiros e humanos, tendo em vista a minimização dos problemas e a maximização dos resultados" (OLIVEIRA, 2006, p. 191).

Estratégia é também "criar uma posição exclusiva e valiosa, envolvendo um diferente conjunto de atividades" (PORTER, 1999, p. 63). Segundo o autor, se houvesse apenas uma posição ideal para as organizações, a estratégia seria desnecessária, pois a busca seria por alcançar aquela posição única. Mas o conceito de estratégia, ou sua essência, segundo Porter (1999), consiste em enfrentar a competição, encontrando "uma posição na 
qual a empresa seja capaz de melhor se defender" contra as chamadas cinco forças básicas que governam a competição numa indústria ou setor, quais sejam: as manobras pelo posicionamento entre os atuais concorrentes, a ameaça de novos entrantes, o poder de negociação dos clientes, a ameaça de produtos substitutos e o poder de negociação dos fornecedores.

Uma empresa só é capaz de superar em desempenho os concorrentes se conseguir estabelecer uma diferença preservável. Ela precisa proporcionar maior valor aos clientes ou gerar valor comparável a um custo mais baixo, ou ambos. Daí decorre a aritmética da rentabilidade superior: o fornecimento de maior valor permite à empresa cobrar preços unitários médios mais elevados; a maior eficiência resulta em custos unitários médios mais baixos. (PORTER, 1999, p. 47)

Estratégia pode também ser entendida como "a seleção e implantação de um conjunto de objetivos com vistas a adaptar a empresa ao ambiente externo ou modificar esse ambiente para melhorar suas chances de sucesso" (COOMBS et al, 1992:9, apud TIGRE, 2006, p. 165).

Porter (1999, p. 52) considera que o lema da estratégia competitiva é ser diferente: "escolher, de forma deliberada, um conjunto diferente de atividades para proporcionar um mix único de valores". Ou ainda, o posicionamento estratégico é "desempenhar atividades diferentes das exercidas pelos rivais ou desempenhar as mesmas atividades de maneira diferente" (PORTER, 1999, p. 48, grifo do autor). O autor afirma que o empreendedor, para ter sucesso, precisa encontrar novas posições, cativar clientes já atendidos por posições existentes ou atrair novos clientes para o mercado.

De acordo com Tigre (2006, p. 167),

A escolha de uma estratégia está associada aos objetivos de seus dirigentes e acionistas. A empresa pode decidir utilizar sua capacitação técnica, gerencial e financeira para buscar alternativas que maximizem o retorno dos investimentos em curto prazo ou pensar em construir uma base tecnológica para o futuro. Pode recorrer a alianças com diferentes parceiros ou atuar de forma independente.

As rápidas mudanças no mercado e a busca por estratégias eficazes trazem à tona, dentre as diversas técnicas gerenciais, o conceito de benchmarking, que consiste em 
“comparações entre empresas concorrentes em dimensões específicas de desempenho empresarial - além de desempenho financeiro - com o objetivo de identificar e atualizar-se em relação à prática mais eficaz” (TIDD; BESSANT; PAVITT, 2008, p. 167).

A técnica é, portanto, é útil para que se possa comparar o desempenho da própria empresa com o desempenho superior de outra organização, obtendo-se conhecimento a ser adaptado para a melhoria da própria organização.

\subsubsection{Tipos de Estratégia}

A literatura apresenta vários tipos de estratégia que podem ser mais adequadas a uma empresa, dependendo de sua capacitação ou dos objetivos pretendidos. Oliveira (2006, p. 197) apresenta seis tipos de estratégias cuja combinação deve se dar de forma a aproveitar todas as oportunidades possíveis, utilizando "a estratégia certa no momento certo":

1) Estratégias de sobrevivência: deve ser adotada quando não existir outra alternativa, ou seja, apenas quando o ambiente e a empresa estão em situação inadequada ou apresentam perspectivas caóticas. Estão incluídas nesse tipo de estratégia as ações de redução de custos, desinvestimento e, em último caso, a liquidação do negócio;

2) Estratégias de manutenção: nesse caso a empresa identifica um ambiente com predominância de ameaças, no entanto, seus pontos fortes acumulados ao longo do tempo como, por exemplo, disponibilidade financeira, recursos humanos ou tecnologia, possibilitam ao executivo, além de buscar sua sobrevivência, manter sua posição conquistada até o momento. Este tipo de estratégia se apresenta de três formas: estratégia de estabilidade, de nicho e de especialização;

3) Estratégias de crescimento: nessa situação o ambiente proporciona situações favoráveis que podem transformar pontos fracos da empresa em oportunidades. São estratégias inerentes ao crescimento: estratégia de inovação, de internacionalização, de joint venture e de expansão;

4) Estratégias de desenvolvimento: estratégias que buscam o desenvolvimento da empresa por meio da procura por novos mercados e clientes, diferentes dos conhecidos ou novas tecnologias, diferentes das que a empresa domina. Este 
desenvolvimento pode se dar de diversas formas: desenvolvimento de mercado, de produtos ou serviços, financeiro, de capacidades, de estabilidade;

5) Ciclo de vida da indústria ou setor: conhecimento da fase do ciclo de vida em que a indústria ou setor se encontram quando se estabelece uma estratégia principal. Tanto o ciclo de vida do produto, da indústria ou setor, apresenta os mesmos estágios: introdução, crescimento, maturidade e declínio.

6) Algumas estratégias funcionais: estratégias de marketing (natureza da linha de bens ou serviços, desenvolvimento de produtos, canais de distribuição, pesquisas de mercado etc.), estratégias financeiras (desinvestimento, obtenção de fundos, financiamento etc.), estratégias de produção (logística, engenharia do produto, engenharia do processo, controle de qualidade etc.) estratégias de recursos humanos (capacitação interna, transferências e promoções, desenvolvimento e treinamento etc.).

A seguir serão abordados alguns conceitos a respeito de inovação, com o objetivo de desenvolver um pouco mais essa estratégia adotada, principalmente, pelas empresas que buscam transformar seus pontos fracos em oportunidades, na busca pelo crescimento.

\subsection{Inovação}

Conforme afirmado anteriormente, dentre as estratégias inerentes à postura de crescimento de uma organização, de acordo com Oliveira (2006) está a busca pela inovação. Nesse caso, segundo o autor, a empresa está sempre preocupada em se antecipar a seus concorrentes, por meio de desenvolvimento e lançamento de novos produtos e serviços, devendo ter acesso rápido e direto a todas as informações necessárias num mercado em rápida evolução.

A inovação fundamenta-se na crença da melhoria crescente. Criação, invenção ou descoberta são idéias novas não-aplicadas. Mudar é aplicar a novidade; é o uso de uma descoberta ou invenção: é introduzir o incomum, tanto no sentido positivo quanto no negativo. A inovação refere-se a uma mudança julgada benéfica; é a solução criativa de problemas, provocando o desenvolvimento da empresa. (MOTTA, 1998, p. 186) 
O economista Joseph Alois Schumpeter, em sua obra Die Theorie der Wirschaftlichen Entwicklung (Teoria do Desenvolvimento Econômico), definiu o que consideramos hoje como marco fundamental do que se entende por inovação. Segundo ele, a idéia se remete a uma nova combinação de recursos concebida, na maioria das vezes, como destruição criadora (em que a criação de algo novo destrói velhas regras e estabelece novas) e essa nova combinação geraria desenvolvimento econômico (SHUMPETER, 1985).

"Schumpeter adota uma concepção abrangente de inovação, associando-a a tudo que diferencia e cria valor a um negócio" (TIGRE, 2006, p. 72). Estão incluídas nessa idéia o desenvolvimento de novos produtos, de novos processos, criação de um novo mercado a exploração de uma nova fonte de suprimentos e a reestruturação de métodos organizacionais.

De uma forma também abrangente, segundo Fiates e Fiates (2008, p.171), inovação é "todo o resultado de uma mudança que propõe uma situação nova para algum aspecto organizacional.” (FIATES; FIATES, 2008, p. 171). Essa mudança pode ser um novo produto, serviço, tecnologia ou mesmo novas práticas organizacionais e o resultado pode ir além dos aspectos exclusivamente econômicos.

As organizações buscam na inovação uma forma de garantir maior competitividade no mercado no qual estão inseridas. Competitividade, de acordo com os mesmos autores (FIATES, 1997, apud FIATES; FIATES, 2008) seria uma capacidade ou competência de a empresa formular e implementar estratégias, que lhe permitam ampliar ou conservar, uma posição sustentável no mercado e seu ambiente de atuação, de forma duradoura.

Segundo Tidd, Bessant e Pavitt (2008), o cenário está gradativamente mudando em favor das organizações que conseguem mobilizar conhecimento e avanços tecnológicos e conceber a criação de novidades em suas ofertas (bens/serviços) e nas formas como criam e lançam essas ofertas. Daí a importância da inovação, pois "há uma forte correlação entre o desempenho mercadológico e a inserção de novos produtos. Produtos novos permitem capturar e reter novas fatias de mercado, além de aumentar a lucratividade de tais mercados" (TIDD; BESSANT; PAVITT, 2008, p. 25).

No cenário atual, portanto, a inovação assume um papel-chave na busca por um diferencial competitivo: 
(...) não há dúvidas sobre a importância da inovação no contexto organizacional. Os avanços científicos e tecnológicos reduzem o ciclo de vida dos produtos e serviços, o que requer das organizações uma capacidade de acompanhar e incorporar inovações em todos os níveis da empresa. Nesse contexto, a inovação é apontada como o diferencial que as organizações deveriam perseguir para alcançar níveis sólidos de competitividade. (FIATES; FIATES, 2008, p. 169)

Segundo Drucker (2005), para se inovar, é preciso monitorar as sete fontes para uma oportunidade inovadora que podem resultar em ações estratégicas que promoveriam a inovação de forma sistemática. O autor dividiu essas sete fontes em dois grupos, sendo o primeiro composto pelas fontes que estariam dentro da organização ou do setor, sendo, portanto visíveis a aqueles que se inserem nesse contexto e o segundo grupo composto por fontes que implicam em mudanças fora da empresa ou do setor.

Fazem parte do primeiro grupo: o inesperado (o sucesso inesperado, o fracasso inesperado, o evento externo inesperado); a incongruência (entre a realidade como ela é e de fato, e a realidade como se presume ser ou como "deveria ser"); a inovação baseada na necessidade do processo e mudanças na estrutura do setor industrial ou na estrutura do mercado que apanham a todos desprevenidos (DRUCKER, 2005).

Já no segundo grupo estão: mudanças demográficas (mudanças populacionais); mudanças em percepção, disposição e significado e o conhecimento novo (tanto científico como não-científico) (DRUCKER, 2005).

\subsubsection{Classificações}

A inovação pode ser classificada de diversas formas, e essas classificações são definidas por vários estudiosos para facilitar a compreensão do fenômeno ou mesmo para auxiliar no processo de gestão de sua implementação. Abaixo serão descritas algumas das classificações encontradas na literatura sobre o tema.

De acordo com o grau de novidade envolvido, as inovações podem ser classificadas como inovações radicais e inovações incrementais. As inovações radicais são as inovações descontínuas, "algo completamente novo ou uma resposta a condições profundamente alteradas" (TIDD; BESSANT; PAVITT; 2008, p. 33). Já as inovações incrementais são 
inovações menores, dentro de paradigmas já existentes, "como um processo contínuo de melhoramentos e técnicas" (JOHANNESSEN; OLSEN; LUMPKIN; apud SANTINI; SOUZA; QUEIROZ; SOUZA FILHO, 2006, p. 222).

A principal classificação de inovação a ser considerada no presente estudo de caso é a inovação incremental, o "fazer o que fazemos melhor" (TIDD; BESSANT; PAVITT, 2008), que será mais bem detalhada a seguir. Segundo esses mesmos autores (2008, p. 33), há estudos acerca do desenvolvimento incremental que indicam que os ganhos cumulativos de eficiência são muito maiores no longo prazo do que os obtidos com as mudanças radicais ocasionais.

Segundo Motta (1998, p. 140), seguindo a mesma linha, afirma que para a mudança incremental ou incrementalismo, definido como o ritual permanente da inovação,

(...) o desenvolvimento organizacional é fruto da introdução moderada e constante de novidades. Interferir de forma permanente na evolução natural favorece o crescimento. A inovação independe da constatação de situações problemáticas ou de rupturas específicas. Inovação faz parte das funções gerenciais. Assim, empreendedores da mudança incremental ressaltam a preservação das conquistas e o controle das incertezas ao introduzir novidades (MOTTA, 1998, p 140).

O mesmo autor (1998, p. 143), acrescenta que a mudança incremental é evolucionária e progressiva, ou seja, "são pequenas intervenções, no dia-a-dia, que adaptam as organizações às imposições externas". Mas essa mudança não se dá, necessariamente, por etapas pré-concebidas e delimitadas no tempo, mas "progride em meio a descontinuidades e tensões, conflitos e contradições, avanços e recuos" (MOTTA, 1998, p. 144).

Tigre (2006, p. 74) afirma que as inovações incrementais são comumente resultado do processo de aprendizado interno e da acumulação acumulada e "abrangem melhorias feitas no design ou na qualidade dos produtos, aperfeiçoamento em layout e processos, novos arranjos logísticos e organizacionais e novas práticas de suprimentos e vendas."

Outro aspecto a ser considerado na classificação da inovação é o aspecto de exclusividade da idéia. Hisrich, Peters e Shepherd (2009), considerando esse aspecto, classificaram em três os tipos principais: inovação revolucionária, inovação tecnológica e inovação comum. 
As inovações revolucionárias são extremamente exclusivas, e definem a plataforma sobre a qual as futuras inovações de uma área serão desenvolvidas. São exemplos de inovações revolucionárias a penicilina, a máquina a vapor, o computador, o avião, o automóvel, a Internet e a nanotecnologia (HISRICH, PETERS, SHEPHERD, 2009).

Já a inovação tecnológica ocorre mais freqüentemente do que a revolucionária. As tecnológicas são inovações que trazem avanços na área de produto ou mercado. $\mathrm{O}$ computador pessoal, o relógio inteligente para conter fotos, a mensagem de voz, e texto e o avião a jato são exemplos desse tipo de inovação (HISRICH, PETERS, SHEPHERD, 2009).

O terceiro tipo de inovação, a inovação comum, é encontrado com mais freqüência, dentre os três tipos. Essas geralmente estendem uma inovação tecnológica para um produto ou serviço melhor ou que tenha um apelo comercial diferente, mais eficaz (HISRICH, PETERS, SHEPHERD, 2009).

Schumpeter (1985) afirma que a nova combinação de recursos, inerentes ao que entendemos por inovação, engloba cinco casos distintos: a introdução de um novo bem, de um novo método de produção, a abertura de um novo mercado, a conquista de uma nova fonte de ofertas de matérias-primas ou ainda o estabelecimento de uma nova forma de organização.

Já para os autores Tidd, Bessant e Pavitt (2008, p. 30), a mudança inerente à inovação pode englobar os chamados 4 P's da inovação: 1) Inovação de produto: mudanças nas coisas (produtos/serviços) que uma empresa oferece; 2) Inovação de processo: mudanças na forma em que os produtos/serviços são criados e entregues; 3) Inovação de posição: mudanças no contexto em que produtos/serviços são introduzidos; 4) Inovação de paradigma: mudanças nos modelos mentais subjacentes que orientam o que a empresa faz.

Segundo esses mesmos autores (2008), os 4 P's da inovação podem se dar, conforme anteriormente citado, de forma incremental (mudanças menores, "fazendo aquilo que fazemos melhor"), podendo chegar a inovações radicais, que transformam a maneira como as coisas são vistas ou utilizadas.

Dessa forma, é no gerenciamento do processo da inovação que a percepção dessas diferenças (mudanças radicais ou incrementais) é considerada importante, pois "as maneiras como lidamos com a mudança incremental diária será diferente daquelas utilizadas ocasionalmente para lidarmos com mudanças radicais em produtos ou processos" (TIDD; BESSANT; PAVITT, 2008, p. 32). 


\subsubsection{Gestão da Inovação}

Motta (1998), ao discorrer sobre gestão da inovação contextualiza a organização moderna como complexa e o seu processo de inovação como sistêmico e globalista, ou seja, qualquer mudança sendo capaz de afetar o todo:

(...) sua condução eficaz requer atenção à totalidade e interdependência, como coordenação e controle do processo de intervenção. Direcionar a mudança torna-se cada vez mais difícil por causa do maior número de variáveis e de imprevistos. Só o começo e a visão imaginária podem ser conhecidos; o final será sempre afetado por forças complexas e emergentes. (MOTTA, 1998, p.140).

O processo de implementação de inovações precisa ser gerenciado, a fim de alcançar os objetivos propostos, pois "o processo de mudança está longe de ter tranqüilidade e segurança. As descontinuidades e conflitos lhe são inerentes e geram a necessidade de coordenação e controle contínuos" (MOTTA, 1998, p. 188).

Nesse sentido, a gestão da inovação pode ser entendida, conforme Bessant (2003 apud SOUSA 2006), englobando as atividades técnicas e comerciais voltadas à implementação bem sucedida de novas idéias e práticas, cuja utilização pode acarretar vantagens competitivas, por meio das quais as organizações podem perdurar e crescer. Consiste em "aprender a encontrar a solução mais apropriada para o problema de gerenciar o processo de maneira eficaz, e fazê-lo pelos meios mais indicados, dadas as circunstâncias em que a empresa se encontra" (TIDD; BESSANT; PAVITT, 2008, p. 62).

Nesse contexto, não se pode negar que a inovação é um processo baseado no conhecimento e aprendizados contínuos. O processo de inovar é arriscado e pode levar a inúmeros fracassos mas, "nem todo processo fracassa; e mesmo em caso de fracasso, algumas empresas (e indivíduos) parecem ter aprendido maneiras de tratá-lo e gerenciá-lo de forma que, ainda que não haja total garantia, ao menos as vantagens a favor do processo de inovação eficaz possam ser aproveitadas" (TIDD; BESSANT; PAVITT, 2008, p. 100). 


\subsubsection{Estratégias de Inovação}

"Estimular a criatividade e a inovação requer muito mais do que um conjunto de ferramentas para ajudar a criar idéias. O processo é centrado em metodologia e estratégias necessárias, como um caminho na direção de alguma solução ou resultado" (BESSANT; TIDD, 2009, p. 67).

Nesse sentido, Freeman (1997, apud TIGRE, 2006) apresenta diferentes tipos de estratégias inovativas que podem ser adotadas pelas empresas em sua trajetória de inovação. O autor ressalva que essas estratégias não são exclusivas, sendo utilizadas pelas empresas em diferentes gradações ou combinações.

Outro aspecto é que essas estratégias não costumam se sustentar em longo prazo, até mesmo por necessitarem de flexibilidade de forma a incorporar mudanças de tecnologias e mercados.

As estratégias de inovação conceituadas pelo autor (1997, apud TIGRE, 2006) são as seguintes:

- Estratégia ofensiva: adotada por empresas que buscam liderança tecnológica em determinados segmentos da indústria. $\mathrm{O}$ inovador geralmente corre grandes riscos inerentes à inovação pioneira, pois introduz uma idéia ainda não testada no mercado.

- Estratégia defensiva: agindo seletivamente em relação à introdução de inovações, as empresas procuram evitar incertezas e erros que levam muitos pioneiros a sucumbir. A empresa que adota uma estratégia defensiva não quer correr o risco de ser a primeira a inovar, mas também não quer ser deixada para trás em termos tecnológicos, portanto ela aprende com os erros dos pioneiros e aproveita a abertura de um novo mercado para oferecer soluções mais seguras e consistentes.

- Estratégia imitativa: a empresa que adota a estratégia imitativa não aspira ser líder ou ter grandes lucros com a introdução da inovação, mas apenas marcar sua presença no mercado, oferecendo um produto semelhante aos existentes.

- Estratégia dependente: as empresas que adotam uma estratégia dependente assumem um papel subordinado em relação a outras empresas mais fortes. Elas não tomam iniciativa de promover mudanças técnicas em seus produtos ou processos, a não ser por demanda explícita de seus clientes ou controladores e dependem de outras empresas para obter as instruções técnicas necessárias para inovar. 
- Estratégia tradicional: a empresa que adota uma estratégia tradicional praticamente não muda seus produtos, seja porque o mercado não demanda mudanças ou porque a concorrência também não inova. Ela geralmente não conta com capacidade técnica para iniciar mudanças, mas pode desenvolver inovações incrementais e fazer pequenas alterações no design do produto com base na experiência prática de seus colaboradores.

- Estratégia oportunista: está associada à exploração de nichos de mercado ou oportunidades temporárias. Sempre existe a possibilidade de empreendedores identificarem alguma nova oportunidade em mercados em rápida transformação que não requeira grandes investimentos em P\&D. Algumas empresas conseguem prosperar encontrando um nicho de mercado que ninguém havia percebido antes e, assim, ir ao encontro de uma demanda de mercado. Estratégia baseada em janelas de oportunidades.

Tigre (2006, p. 178) ainda afirma que

\begin{abstract}
As estratégias competitivas nem sempre são explícitas, podendo ser adotadas intuitivamente sem nenhuma formalização. Elas estão relacionadas à percepção de capacitações dinâmicas internas da empresa e também ao ambiente externo, seja setorial, regional ou internacional. A combinação das oportunidades e dificuldades internas e externas constitui o elemento essencial para uma estratégia de sucesso (TIGRE, 2006, p. 178).
\end{abstract}

\title{
2.3. Inovação e Sustentabilidade
}

A responsabilidade social das organizações e o comportamento ético dos administradores, segundo Maximiano (2006) estão entre as tendências mais importantes do mundo atual. Nesse sentido, emergem conceitos como sustentabilidade e desenvolvimento sustentável.

Criado pela Comissão Mundial do Ambiente e do Desenvolvimento (apud Maximiano, 2006, p. 435), o conceito de desenvolvimento sustentável se remete ao "desenvolvimento que atende às necessidades do presente sem comprometer a capacidade de atendimento das necessidades das gerações futuras."

Conforme Bessant e Tidd (2009) a inovação é geralmente apontada como a mais importante contribuição para a degradação do meio-ambiente, já que seu conceito está associado ao aumento do crescimento econômico e do consumo. No entanto, conforme os 
autores, a inovação pode ser parte importante de qualquer solução possível para questões ambientais, oferecendo:

- Produtos mais limpos - com impacto ambiental menor ao longo de seu ciclo de vida;

- Produtos mais eficientes - para minimizar ou tratar resíduos, reutilizá-los ou reciclá-los;

- Tecnologias alternativas - para reduzir emissões, fornecer energia renovável;

- Novos serviços - para substituir ou reduzir o consumo de produtos;

- Inovações sistêmicas - para mensurar e monitorar o impacto ambiental, novos sistemas sociotécnicos.

Os autores apresentam, ainda, uma tipologia das diferentes maneiras pelas quais a inovação pode contribuir para a sustentabilidade, como pode ser visualizado na Figura 2.1:

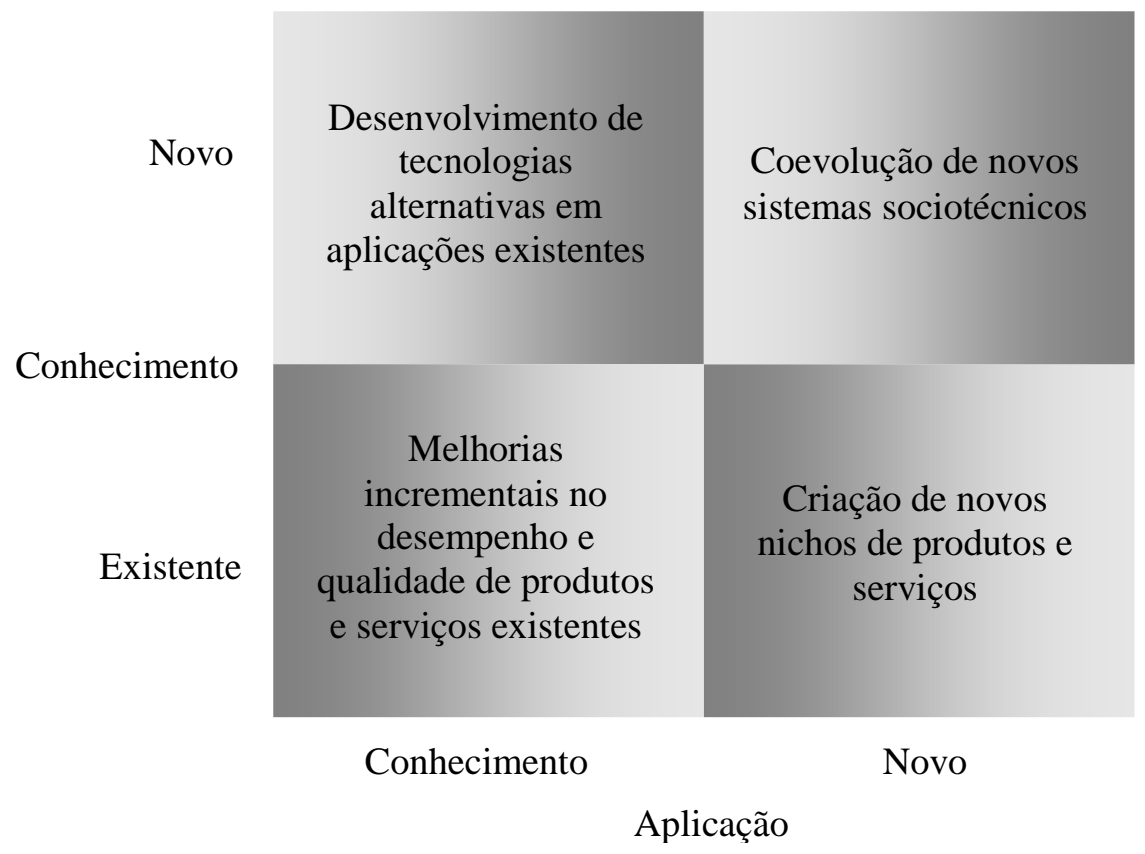

Figura 2.1 - Uma tipologia de inovações sustentáveis Fonte: Bessant; Tidd, 2009, p. 361.

Conforme mostra a Figura 2.1, uma dimensão é a inovação de conhecimento e a outra é a inovação da aplicação desse conhecimento. No quadrante inferior esquerdo, a inovação concentra-se em melhoria de tecnologias, produtos e serviços existentes. Já o 
quadrante superior esquerdo representa o desenvolvimento de novo conhecimento, mas considera sua aplicação a problemas existentes. O quadrante inferior direito representa a aplicação de conhecimento existente para criar novos nichos de mercado. Já o quadrante superior direito é, provavelmente, a contribuição mais fundamental da inovação para a sustentabilidade. A coevolução de sistemas sociotécnicos. Nele, desenvolvedores e usuários de inovação interagem de maneira mais próxima, e muito mais participantes são envolvidos no processo de inovação. Entra em cena uma série de externalidades: infra-estrutura de apoio, produtos e serviços complementares, finanças e novos treinamentos e habilidades. Tais inovações geralmente são desenvolvidas a partir de uma combinação de mudança de política e coordenação de cima para baixo, mudança social e de comportamento empresarial de baixo para cima.

$\mathrm{Na}$ mesma linha de pensamento a respeito da importância da inovação para a sustentabilidade, Porter (1999, p. 395) afirma que a competitividade depende da utilização produtiva dos recursos.

\begin{abstract}
As empresas têm condições de melhorar a produtividade dos recursos através da fabricação dos produtos existentes com maior eficiência ou do desenvolvimento de produtos que sejam mais valiosos para os clientes pelos quais os clientes estejam dispostos a pagar preços mais elevados. Cada vez mais, os países e as empresas que apresentam maior competitividade não são aqueles com acesso aos insumos de custo mais baixo, mas os que empregam a tecnologia e os métodos mais avançados na sua utilização. Como a tecnologia se encontra em constante processo de mudança, o novo paradigma da competitividade global exige a capacidade de inovar com rapidez. (PORTER, 1999, p. 395).
\end{abstract}

O autor afirma ainda que este novo paradigma tem profundas implicações no debate sobre política ambiental e foi responsável por entrelaçar a melhoria ambiental e a competitividade. Ressalta a importância de se utilizar os recursos de forma produtiva, sejam eles naturais e físicos ou humanos e de capital. "O progresso ambiental exige que as empresas sejam inovadoras para aumentar a produtividade dos recursos - e é exatamente nesse ponto que se situam os novos desafios da competitividade global" (PORTER, 1999, p. 395). 


\subsection{Inovação em Agronegócios}

Crestana e Silva (2006) acreditam que, motivadas pela necessidade de sobrevivência, as primeiras inovações terão ocorrido no espaço rural:

Recolher sementes espalhadas pela floresta e semeá-las de forma mais concentrada numa área delimitada, protegida de inimigos e animais e mais próxima da moradia, para facilitar a colheita e armazenagem dos alimentos, foi um gesto inovador e radical: inventou a agricultura, que mudou completamente a vida no planeta Terra. (CRESTANA; SILVA, 2006, X)

Em agronegócios, existem dois tipos básicos de produtos que o produtor rural pode produzir, quais sejam, as commodities e os bens especiais agroalimentares, sendo esse último tipo nomenclatura atribuída por Zuin (2004 apud ZUIN; QUEIROZ, 2006, p. 253).

Segundo Zuin e Alliprandini (2006), commodities são produtos geralmente produzidos em grandes áreas, e empregam nos seus processos produtivos, tecnologia de ponta.

São considerados produtos de pouco valor agregado. Para serem consideradas como tais, as commodities devem atender a três requisitos: padronização internacional, possibilidade de entrega em datas acordadas entre comprador e vendedor, e possibilidade de ser estocado e vendido em unidades padronizadas (ZUIN, ALLIPRANDINI, 2006).

O preço dessa categoria de produtos é regulado externamente pelo mercado e o produtor rural não possui nenhuma ou quase nenhuma influência nesse processo. As commodities mais conhecidas no Brasil são: soja em grão, açúcar, café e suco concentrado de laranja (ZUIN, ALLIPRANDINI, 2006).

Já os produtos do tipo bens especiais agroalimentares são aqueles que passam por algum tipo de transformação, sendo ela mínima ou total e/ou podem receber algum tipo de certificação, como é o caso dos produtos orgânicos. São considerados produtos mais sofisticados e o preço pago por esses produtos não é tão intensamente regulado pelo mercado, podendo o produtor rural definir, com maior liberdade, seu preço e venda (ZUIN, ALLIPRANDINI, 2006).

A competitividade do empreendimento rural, de um modo geral, está intimamente ligada à agregação de valor, possibilitada, na maioria das vezes, pela inovação. Agregar valor 
é buscar sua diferenciação, sua "descomoditização" conforme Lazzarini (1997 apud VILCKAS; NANTES; 2006). "Agregar valor aos produtos de origem rural tornou-se uma questão fundamental para os produtores, por meio da qual esses podem permanecer e alcançar novos mercados." (VILCKAS; NANTES, 2006, p. 176).

Nesse sentido, conforme os autores, os bens especiais agroalimentares seriam uma alternativa às commodities, pois a eles é possível imprimir maior agregação de valor. Segundo Lazzarini (1997 apud VILCKAS; NANTES, 2006), a empresa busca sair da situação de tomadora de preços e, dentro de certos limites, busca impor seu preço ao produto, de acordo com sua política mercadológica.

Dentre os aspectos relacionados à agregação de valor aos empreendimentos rurais, o mais preocupante é relacionado à gestão do negócio:

A competitividade das empresas depende fortemente da capacidade de
gestão do empreendimento, que quando corretamente realizada, permite a
incorporação de tecnologia aos processos, a melhoria da qualidade da
informação e uma eficiente coordenação das atividades de produção e
comercialização. No setor rural, a gerência do negócio também assume
grande importância; no entanto, o processo de gestão nesse segmento é
particularmente mais difícil de ser realizado (VILCKAS, NANTES, 2006, p.
169).

Segundo os autores (2006), essa dificuldade está condicionada a vários fatores, como variações climáticas, sazonalidade, perecibilidade dos produtos, dentre outros. O setor rural também não possui um modelo de gestão adequado à sua realidade. "Entre os possíveis motivos para essa dificuldade destacam-se as diferenças regionais em termos de clima, solo, disponibilidade e capacitação de mão-de-obra, distância dos mercados consumidores, diferentes mix de atividades produtivas, entre outras" (VILCKAS, NANTES, 2006, p. 169).

A gestão do empreendimento rural, que compreende coleta de dados, geração de informações e tomada de decisão, é insuficientemente tratada na literatura. Os trabalhos existentes nessa área são restritos aos aspectos relacionados a custos, finanças e contabilidade. São incipientes os esforços dedicados a outras ferramentas de gestão, tais como definição do produto e do processo de produção, sistema de qualidade, planejamento e controle da produção, etc. Além disso, os mecanismos de divulgação não são suficientes para capacitar o produtor na implementação e utilização das técnicas disponíveis (NANTES, SCARPELLI, apud VILCKAS, NANTES, 2006, p. 169). 
A fim de que essa dificuldade possa ser, de alguma forma, minimizada, Vilckas e Nantes (2006) propõem que a utilização de planejamento das atividades produtivas (entendido como um processo que compreende a definição de metas e o estabelecimento de uma estratégia global para o alcance das metas) seja feito de forma criteriosa, bem como sejam aprofundadas as noções relacionadas à agregação de valor aos produtos, "tornando-os mais práticos e seguros, podendo, dessa forma, conquistar novos mercados" (VILCKAS, NANTES, 2006, p. 170).

\subsubsection{Produtos Orgânicos}

Considerando que a empresa objeto do presente estudo de caso atua no mercado de produtos orgânicos, a seguir serão apresentados alguns conceitos que particularizam esse tipo de produção.

De uma forma geral, o produto orgânico é todo produto, animal ou vegetal, obtido sem a utilização de produtos químicos ou de hormônios sintéticos que favoreçam o seu crescimento de forma não natural (ORGANICSNET, 2009). Os vegetais resultariam, portanto, em produtos livres de agrotóxicos, pesticidas, adubos químicos ou sementes transgênicas. Já no caso de animais, a especificidade está na forma de criação feita sem o uso de hormônios de crescimento, anabolizantes ou antibióticos.

De acordo com Borguini e Torres (2006),

\footnotetext{
'Orgânico' é um termo de rotulagem que indica que o alimento é produzido de acordo com normas específicas que vetam o uso de quaisquer agroquímicos e que está certificado por uma agência devidamente constituída. Esta revisão discute as distinções entre os alimentos orgânicos e convencionais, com respeito à qualidade nutritiva e à segurança do alimento, e evidencia a existência de diversas diferenças qualitativas (BORGUINI; TORRES, 2006, p. 64).
}

Apesar de não haver consenso entre os estudiosos por conta da escassez de estudos científicos sobre o assunto, atribui-se à forma de produção orgânica, a vantagem de os produtos serem mais saudáveis, naturais, e os solos onde são cultivados mais férteis e livres de produtos tóxicos, garantindo maior equilíbrio ambiental e, por conseqüência, maior sustentabilidade. 
Segundo Borguini e Torres (2006), dentre os produtos orgânicos cultivados no Brasil com fins de exportação, merecem destaque a soja, o café, o cacau, o açúcar mascavo, a ervamate, o suco de laranja, mel, frutas secas, castanha de caju, óleos essenciais, óleo de palma, frutas tropicais, palmito, guaraná e arroz. No consumo interno, há uma prevalência no consumo de produtos in natura, como as hortaliças.

Ainda sobre o consumo interno, percebe-se que demanda por alimentos produzidos sem agrotóxicos e menos agressivos ao meio-ambiente é uma tendência crescente no país, no entanto, o preço desses produtos é considerado um fator limitante.

Segundo Souza \& Alcântara (2003 apud BORGUINI; TORRES, 2006), no mercado de produtos orgânicos não existe um parâmetro definido para o estabelecimento de preços, mas sabe-se que as estratégias de atribuição de preços variam amplamente de acordo com o estabelecimento comercial.

Observa-se que, nas grandes redes varejistas, a diferença cobrada acima dos produtos convencionais é elevada, enquanto nas feiras de produtos orgânicos esta diferença é reduzida. Em média, os produtos orgânicos in natura são $40 \%$ mais caros, quando comparados aos produtos convencionais, porém, alguns produtos, como o trigo e o açúcar, chegam a custar (venda ao atacado), respectivamente, $200 \%$ e $170 \%$ acima do produto convencional.

Segundo a publicação BNDES Setorial (2002), um produto considerado orgânico, em geral, não apresenta muitas diferenças aparentes, se comparado a um produto chamado convencional, seja na forma, cor, ou mesmo sabor. Assim, o que normalmente leva o consumidor a consumi-lo são as informações a respeito de suas vantagens nutricionais, a ausência de insumos tóxicos, além da confiança na veracidade dessas informações, sendo um bem que tem na confiança o seu principal valor.

No Brasil, a legislação que dispõe sobre a Agricultura Orgânica é a Lei 10.831/2003, regulamentada pelo Decreto 6.323/2007. A partir da publicação do decreto, o sistema produtivo da Agricultura Orgânica passou a ter critérios legais para o funcionamento de seu processo produtivo.

Foi criado o Sistema Brasileiro de Avaliação da Conformidade Orgânica, composto pelo Ministério da Agricultura, Pecuária e Abastecimento (MAPA), órgãos fiscalizadores dos estados e organismos de avaliação da conformidade orgânica. Nesse processo, o ministério credencia, acompanha e fiscaliza os organismos, que serão previamente habilitados no MAPA, após passarem por processo de acreditação no Instituto Nacional de Metrologia, 
Normalização e Qualidade Industrial (INMETRO), e estes organismos, após habilitados, atuarão na certificação da produção orgânica, bem como na prestação de informações a respeito de sua área de atuação para alimentar o cadastro nacional de produtores orgânicos.

Sobre o mercado de orgânicos no Distrito Federal, universo de interesse do presente estudo de caso, foi publicado, em uma pesquisa apresentada pela Emater-DF, em dezembro de 2005, considerando, o diagnóstico do perfil do consumidor desse tipo de produto na região, bem como o que esse público deseja do mercado.

Os resultados da pesquisa indicaram que o hábito de consumo de produtos orgânicos no DF é recente. A maioria das pessoas pesquisadas no final de 2006 consumia produtos orgânicos há menos de cinco anos. Esse consumo era, também, considerado eventual, mas com intenções claras de ampliação.

A principal faixa de consumidores de produtos orgânicos no DF é composta por indivíduos acima de 45 anos e de rendas médias elevadas, sendo a renda um fator condicionante para o consumo desses produtos.

A pesquisa apontou também que o mercado de orgânicos tem grande potencial de crescimento, já que foi identificado que a demanda por orgânicos é bastante superior à oferta.

\subsubsection{Produtos Minimamente Processados}

Lopes e Nantes (2006, p. 368) afirmam que "o aumento da concorrência em seus mercados atuais e a disputa por novos e melhores mercados têm impulsionado transformações significativas no meio rural". O produtor rural busca modernizar e aceita maiores mais riscos, apostando na tecnologia para dar sustentabilidade ao seu negócio.

Nesse sentido, Santini, Souza, Queiroz e Souza Filho (2006) afirmam que as novas necessidades impostas pelo mercado contribuem para a implementação de inovações em todos os segmentos que compõem a cadeia agroindustrial.

Nesse sentido, Zuin e Alliprandini (2006) afirmam que uma das alternativas encontradas pelo empresário rural atualmente é a produção os produtos, como, por exemplo, as frutas e legumes, de forma minimamente processada.

Da mesma forma, afirmam Santini, Souza, Queiroz e Souza Filho (2006), 
É crescente, por parte do produtor rural, a preocupação em produzir com qualidade, pensando-se não somente em técnicas que não denigram o meio ambiente como em comercializar o produto em condições mais adequadas, como minimamente processados, lavados e embalados. (SANTINI; SOUZA; QUEIROZ; SOUZA FILHO; 2006, p. 221).

Segundo Beaulieu et al, (1997 apud SOARES, 2002), tem-se verificado um grande interesse na produção de frutas e hortaliças minimamente processados, devido a acentuadas mudanças no estilo de vida das pessoas, diminuindo o tempo para preparo desses alimentos tanto em nível familiar, quanto em restaurantes de comidas rápidas ou hotéis.

Os produtos semiprocessados têm um mercado crescente no varejo, atendendo a um público de maior poder aquisitivo. Um exemplo são os vegetais minimamente processados, vegetais frescos que, após passarem por etapas mínimas de processamento, são oferecidos de forma prática, saudável e pronta para o consumo (FARES; NANTES, 2001, apud VILCKAS; NANTES, 2006, p. 181).

Wiley (1994 apud SOARES, 2002) afirma ainda que esses produtos minimamente processados apesar de submetidos a pequenas modificações das condições naturais, ainda possuem características de alimentos frescos.

A matéria-prima, conforme Luengo e Lana (1997 apud NANTES; LEONELLI, 2000) é selecionada, lavada, cortada e embalada dentro de padrões de qualidade exigidos pelo mercado. Esses produtos são apresentados em cubos, picados e ralados ou em mix de saladas. O processo é mais usado em verduras e legumes, mas é também utilizado em frutas.

Segundo Nantes e Leonelli (2000), o processamento mínimo reduz a vida útil da matéria-prima devido à aceleração do metabolismo, sendo necessário o uso de embalagens adequadas, associado à refrigeração, como prática indispensável à melhor conservação.

A produção desse tipo de produto deve ter como princípios a busca por qualidade superior, pois, segundo os autores acima citados, o público consumidor desse tipo de produto é considerado seletivo e exigente. 
(...) deve-se priorizar o padrão de qualidade já na produção, utilizando-se variedades de acordo com as preferências do consumidor (cor, tamanho e sabor), escolha correta dos insumos e viabilização do cultivo orgânico, para o fornecimento constante e com qualidade homogênea. (NANTES; LEONELLI, 2000, p. 65)

Os autores acreditam, inclusive, que a principal promoção, desse tipo de produto, é a sua qualidade. "Se na primeira compra o consumidor verifica que o produto foi bem processado, conserva o frescor, apresenta maior durabilidade, e é mais prático, repetirá a compra" (NANTES; LEONELLI, 2000, p. 67). A cor, o sabor, a textura, a embalagem e os aspectos nutricionais são, portanto, importantes diferenciais na decisão de compra. 


\section{MÉTODOS E TÉCNICAS DE PESQUISA}

A metodologia de pesquisa utilizada no presente estudo de caso será, a partir deste ponto, mais bem detalhada, a fim de que se possa perceber que os meios escolhidos foram os mais adequados para a consecução dos fins a que o trabalho se propõe.

A seguir serão apresentados os métodos que delinearam a pesquisa e os caminhos que foram percorridos, desde a sua concepção, em busca dos objetivos propostos.

\subsection{Delineamento da Pesquisa}

Considerando os objetivos propostos e a forma como foram perseguidos, a monografia tem o seguinte delineamento:

Quanto aos níveis de pesquisa ou, de acordo com os objetivos, a pesquisa é descritiva, tendo a forma de estudo de caso do tipo "estudo de caso único", em que uma só empresa foi estudada em profundidade. O estudo de caso, de acordo com Yin (2005), é a estratégia utilizada quando se buscam repostas às questões do tipo "como" e "por que" e o pesquisador tem pouco controle sobre os acontecimentos e quando se trata de fenômenos contemporâneos inseridos em algum contexto da vida social.

Ainda segundo o autor (2005, p. 27), “o poder diferenciador do estudo de caso é a sua capacidade de lidar com uma ampla variedade de evidências - documentos, artefatos, entrevistas e observações - além do que pode estar disponível no estudo histórico convencional."

Conforme Schramm (1971, apud YIN, 2005, p. 31), "a essência de um estudo de caso (...) é que ela tenta esclarecer uma decisão ou um conjunto de decisões; o motivo pelo qual foram tomadas, como foram implementadas e com quais resultados. Considerando os objetivos propostos pelo presente trabalho, pode-se afirmar, portanto, que o estudo de caso é a melhor maneira de estudar o problema proposto.

Quanto à utilização dos resultados, de acordo com Andrade (2005) pode-se dizer que se trata de pesquisa fundamental, uma vez que motivada, principal e essencialmente, por 
razões de ordem intelectual, para a aquisição de conhecimentos. No entanto, a mesma autora afirma que a pesquisa fundamental pode, eventualmente, proporcionar conhecimentos passíveis de aplicações práticas, aproximando-se, portanto da pesquisa aplicada, o que poderia ser considerado uma pretensão, ainda que ousada, quanto à utilização dos resultados do presente estudo de caso, ou seja, que seus resultados venham a contribuir com a busca de soluções para problemas concretos.

Quanto aos procedimentos de coleta, foi utilizada, a pesquisa bibliográfica, pois se utilizou, para que fosse possível desenvolver o estudo de caso sobre a empresa escolhida, a leitura exaustiva de livros, publicações como artigos, revistas periódicas e, ainda, consulta a sítios da internet, de modo que se pudesse ter uma noção inicial, vasta e abrangente sobre o universo teórico cujo entendimento era almejado, buscando-se, conhecer a teoria já escrita sobre os assuntos propostos.

Cooper (1984, apud YIN, 2005) afirma que a determinação das questões mais significantes para um determinado assunto e para obter maior precisão na formulação de questões é exigida preparação, sendo uma das maneiras de se conseguir isso, a revisão da literatura sobre o assunto.

(...) essa revisão de literatura é, portanto, um meio para se atingir uma finalidade, e não, - como pensam muitos estudantes - uma finalidade em si. Os pesquisadores iniciantes acreditam que o propósito de uma revisão de literatura seja determinar as respostas sobre o eu se sabe a respeito de um tópico; não obstante, os pesquisadores experientes analisam pesquisas anteriores para desenvolver questões mais objetivas e perspicazes sobre o mesmo tópico. (YIN, 2005, p., 28, grifo do autor)

A partir daí, para a obtenção dos resultados propostos, foi uma pesquisa de campo, dentro da Instituição, utilizando-se, principalmente a observação direta. Observar, conforme Barros e Lehfeld (1986, p. 80) "aplicar atentamente os sentidos a um objeto para dele adquirir um conhecimento claro e preciso".

Ainda como instrumento de coleta de dados, foi utilizada a ferramenta "entrevista semi-estruturada", tratando-se, enquanto modalidade de aplicação, de uma pesquisa qualitativa. "A pesquisa de campo assim é denominada porque a coleta de dados é efetuada 'em campo', onde ocorrem espontaneamente os fenômenos, uma vez que não há interferência do pesquisador sobre eles" (ANDRADE, 2005, p. 127). 
A entrevista semi-estruturada, ou parcialmente estruturada, conforme denominação de Gil (1996, p. 92) é considerada adequada neste caso, pois esta é "guiada por uma relação de pontos de interesse que o entrevistador vai explorando ao longo de seu curso". Ou seja, foram utilizadas perguntas abertas que permitiram a condução de novas questões a serem exploradas, de acordo com a perspectiva dos entrevistados e de novos caminhos que se mostravam passíveis de serem mais bem detalhados, ao longo da entrevista, que viessem a corroborar com os objetivos propostos.

Foram investigados, de forma qualitativa, aspectos voltados à gestão da organização, suas estratégias, as dificuldades encontradas em sua trajetória, processo de implementação de inovações, seus sucessos, seus fracassos nesse processo, tendo como objetivo verificar que aspectos particulares à gestão da organização a colocam num patamar de destaque no setor de Agronegócios no Distrito Federal (SEBRAE, 2008).

\subsection{Descrição dos Elementos de Pesquisa}

A pesquisa buscou levantar informações a respeitos de três elementos ou áreas principais da empresa, quais sejam, Produção Agrícola, Processamento Pós-Colheita, Comercialização e Gestão.

Apesar de a empresa também ofertar produtos derivados da produção leiteira (leites, iogurtes, queijos), para fins didáticos, delimitou-se a pesquisa à produção agrícola, apenas.

\subsection{Participantes do Estudo}

Para a coleta de informações em campo, foram entrevistadas cinco pessoas, dentre proprietária, funcionários e consultor externo.

As informações relativas à produção agrícola foram coletadas por meio de entrevistas com um dos proprietários da empresa, a Engenheira Agrônoma Clevane Pereira, além de um funcionário cuja experiência é voltada tanto para produção e processamento pós-colheita (ou industrialização, como é chamado pela empresa) e o consultor externo em produção orgânica, que presta consultorias periódicas à empresa, há cerca de cinco anos. 
Já as informações relativas ao processamento pós-colheita foram, principalmente, coletadas por meio de entrevista com dois funcionários, um de nível técnico, mas de larga experiência na empresa (também entrevistado a respeito de produção agrícola) e também um funcionário de nível superior, Engenheiro Agrônomo, mas que possui menos tempo de experiência na empresa.

As entrevistas relacionadas à gestão da empresa e comercialização dos produtos foram feitas à proprietária da empresa e também a uma funcionária, cujas atribuições são voltadas a essas duas áreas.

\subsection{Procedimentos e Instrumentos Utilizados na Coleta e Análise dos Dados}

Conforme Gil (1996, p. 122), a "coleta de dados no estudo de caso é feita mediante o concurso dos mais diversos procedimentos", sendo os mais usuais, segundo o autor, a observação, a análise, os documentos, a entrevista e a história de vida.

O primeiro contato com a empresa se deu por meio de reunião agendada com um dos proprietários da empresa, a Engenheira Agrônoma Clevane Pereira, no escritório existente no Plano Piloto, em Brasília, ocasião em que foram descritas as noções gerais a respeito da pesquisa, seus objetivos, principais hipóteses, seguido da solicitação de autorização da empresa para que fossem conduzidos os trabalhos.

A partir daí, foi agendada uma primeira visita à empresa, visita esta que aconteceu de forma guiada, com um grupo de 35 pessoas que se dirigiram à Chácara 16 da Colônia Agrícola Lamarão, a $70 \mathrm{~km}$ de Brasília, onde está situada a sede da empresa e onde os produtos comercializados pela organização são produzidos e processados.

Nesse ponto pode-se dizer que a observação direta foi um importante instrumento de coleta de dados, uma vez que na observação direta estão incluídas "observações de reuniões, atividades de passeio, trabalho de fábrica, salas de aula e outras atividades semelhantes (YIN, 2005, p. 120).

Essa atividade oferecida pela empresa e que acontece periodicamente, tem como principais atrativos uma visita guiada a locais-chave da organização, notadamente os locais onde são produzidos e processados os alimentos. Além disso, palestras que são proferidas 
pelos proprietários e alguns funcionários da organização, em que são explicados aspectos relacionados ao dia-a-dia da empresa e são esclarecidas dúvidas a respeito da produção orgânica, sendo possível, ainda, por parte dos visitantes, a interação com os palestrantes por meio de comentários e perguntas, e até documentação fotográfica.

Nesse ponto é possível perceber que uma importante oportunidade de coleta de informações relevantes aos objetivos do trabalho puderam ser coletados, sob a forma de observação, de maneira a corroborar com a pesquisa.

Posteriormente à data da visita, foi solicitado o agendamento de entrevistas com os funcionários da organização, conforme descrito na parte do trabalho dedicada a "Participantes do Estudo". Por se tratar de entrevistas semi-estruturadas, foram levados a campo, questionários contendo perguntas, previamente formuladas, relacionadas às áreas, de Produção Agrícola, Processamento Pós-Colheita, Comercialização e Gestão.

As entrevistas relativas a Gestão e Comercialização aconteceram no escritório em Brasília, onde o core dessas atividades é realizado e as entrevistas sobre Produção Agropecuária e Processamento Pós-Colheita aconteceram na sede da empresa.

As perguntas levadas a campo tiveram como fonte de inspiração e foram adaptadas aos objetivos da pesquisa a partir do instrumento questionário utilizado na Pesquisa de Inovação Tecnológica 2005, realizado pela Diretoria de Pesquisas / Coordenação de Indústria, do Instituto Brasileiro de Geografia e Estatística.

Para fins de exemplificação, seguem algumas das perguntas levadas a campo, na oportunidade das entrevistas, divididas pelas áreas investigadas:

- Produção Agropecuária: "Nos últimos cinco anos houve a implementação de algum produto novo ou substancialmente aperfeiçoado pela empresa?" "Quais as principais dificuldades pela empresa quando da introdução dessas inovações?"

- Processamento pós colheita: "Nos últimos cinco anos a empresa introduziu alguma forma nova ou significativamente aperfeiçoada de apresentação de seus produtos, advindas do processamento pós-colheita?" "Nos últimos cinco anos, a empresa abandonou algum projeto de introdução de melhoria no processamento pós-colheita?"

- Comercialização: "Nos últimos cinco anos a empresa introduziu alguma forma nova ou significativamente aperfeiçoada de comercialização de seus produtos?" "Algum novo serviço foi introduzido?" 
- Gestão: "Nos últimos cinco anos, a empresa implementou alguma mudança significativa na sua estratégia corporativa?" "Quais as principais dificuldades encontradas na gestão da empresa atualmente?"

\subsection{Período de Realização da Pesquisa}

A pesquisa de campo foi realizada entre a segunda quinzena do mês de maio e primeira quinzena do mês de junho de 2009, tendo iniciado com uma visita guiada à empresa, seguida visita ao escritório da empresa no Plano Piloto, em Brasília, para a realização das entrevistas a respeito do processo de comercialização e gestão organizacional. Posteriormente, foi feita uma segunda visita à sede da empresa, onde foram realizadas as entrevistas sobre o processo produtivo agrícola e o processamento pós-colheita.

\subsection{Comentários Sobre o Processo da Coleta de Dados}

O relato do caso estudado foi feito a partir da análise meticulosa dos dados e informações coletados em campo, por meio das entrevistas e observação direta, para fins de conduzir as "constatações e resultados para a conclusão" (YIN, 2005, p. 171).

Foi utilizada a narrativa simples para descrever o caso, mas dividida entre as áreas temáticas escolhidas, quais sejam, produção agrícola, processamento pós-colheita, comercialização e gestão. Para fins didáticos, foram também utilizadas tabelas contendo resumos dos principais temas desenvolvidos no relato do caso, além do uso de imagens, que ilustram alguns dos aspectos abordados.

Para o alcance dos fins buscados pelo trabalho, foi utilizada, essencialmente, no seu relato, estrutura ilustrativa para a composição de estudos de caso não-seqüencial, conforme metodologia de Yin (2005), "aquela em que a ordem das seções ou capítulos não possui uma importância em especial” (YIN, 2005, p. 185), ou seja, a ordem em que são descritas as seções não é um aspecto essencial para o bom entendimento do relato. Segundo o autor, os estudos de caso descritivos, freqüentemente, apresentam essa característica. 


\section{RESULTADOS E DISCUSSÕES}

A partir desse ponto serão apresentados os principais dados coletados na pesquisa a respeito da empresa Fazenda Malunga, relatados de forma a buscar o melhor entendimento do problema proposto para análise.

A escolha pela separação por áreas da empresa, utilizada no relato apresentado a seguir, norteou a pesquisa, desde sua concepção, conforme já informado, tendo sido uma escolha consciente, para melhor visualização e entendimento do caso estudado.

Como um dos objetivos específicos do presente trabalho, os entrevistados foram solicitados a falar sobre as dificuldades enfrentadas atualmente pela empresa, em todas as áreas investigadas, e esses dados foram organizados no final de cada seção (Produção, Processamento Pós-Colheita, Comercialização e Gestão), de forma a enriquecerem o conhecimento a respeito da empresa estudada.

Conforme informado anteriormente, é importante salientar que, apesar de a empresa possuir uma área dedicada à Pecuária, com produção de produtos derivados de leite, como iogurtes, leites do tipo desnatado e integral, creme de leite fresco, queijo minas frescal e padrão, dentre outros, para fins didáticos, o presente relato se restringe à produção agrícola limitada a produção de verduras, frutas e legumes.

\subsection{Superação de Obstáculos e Inovações na Produção Agrícola}

Considerando os cinco últimos anos, pode-se perceber que as principais dificuldades encontradas pela empresa Fazenda Malunga em seu processo produtivo consistiram na aplicação eficaz de tecnologias já conhecidas, porém de forma consciente, visando à garantia de maior produtividade, ou seja, maior produção com menor custo.

A melhoria da qualidade dos produtos também foi (e ainda é) um desafio da empresa, o que requereu e requer muita pesquisa e experimentos dentro da empresa e parcerias com algumas instituições, como a Universidade de Brasília, em busca de melhores produtos. 
Outra dificuldade inerente ao processo produtivo se refere à qualidade e ao acesso a insumos orgânicos (adubos, fertilizantes) de boa qualidade, matéria-prima não facilmente encontrada no mercado do Distrito Federal.

Abaixo, no Quadro 4.1, são apresentadas algumas das dificuldades identificadas pela empresa nos últimos cinco anos e as principais ações colocadas em prática para superação destas, no que tange à produção agrícola.

\begin{tabular}{|l|l|}
\hline \multicolumn{1}{|c|}{ Principais obstáculos } & \multicolumn{1}{c|}{ Como foram superados } \\
\hline - Aumento da produtividade & $\begin{array}{l}\text { ・ Análise de gestão do produto } \\
\text { - Quatro etapas de melhorias na produção }\end{array}$ \\
\hline - Melhoria da qualidade dos produtos & $\begin{array}{l}\text { - Conhecimento da necessidade nutricional de cada } \\
\text { espécie plantada }\end{array}$ \\
\hline - Qualidade/acesso ao insumo orgânico & $\bullet$ Insumo produzido pela empresa \\
\hline
\end{tabular}

Quadro 4.1 - Superação de obstáculos em produção agrícola pela Fazenda Malunga

Fonte: Dados de pesquisa, elaborado pela autora, junho de 2009.

Dentre os desafios que uma empresa de produtos orgânicos pode enfrentar, os entrevistados afirmaram que, no caso da empresa Fazenda Malunga, aspectos relacionados ao aumento da produtividade, à melhoria da qualidade dos produtos e à qualidade dos insumos podem ser consideradas as dificuldades mais relevantes nos últimos cinco anos.

Para que as dificuldades relacionadas ao aumento da produtividade fossem enfrentadas, algumas inovações foram implementadas, como a utilização de técnica relacionada à gestão do produto e experimentação com a introdução de algumas técnicas de melhorias na produção agrícola, advindas da contratação de um consultor em produção orgânica. O conjunto dessas técnicas pode ser considerado de fundamental importância para os resultados obtidos na produção agrícola atualmente.

A produção atual da Fazenda Malunga pode chegar a 85 mil itens por semana, somente considerando-se a produção de hortaliças e, para se chegar a esse montante, muita experimentação, tentativas e erro, e também muitas técnicas agrícolas tradicionais e voltadas à produção orgânica foram implementadas.

Do montante de produção semanal citado acima, um percentual de $30 \%$ se refere ao produto alface americana, hoje o produto mais vendido pela empresa. A respeito desse produto, pode-se citar a dificuldade encontrada pela empresa para encontrar a época certa para 
a adubação da espécie, que somente foi possível após anos de experiência com adubação orgânica.

Outro produto que demandou muita experimentação foi o tomate orgânico, cuja semente normalmente encontrada no mercado não é adequada para produção orgânica, devido ao tratamento dado à semente voltada à produção convencional.

Após anos de estudos desenvolvidos internamente na empresa e por meio de parcerias com institutos de pesquisa, chegou-se a uma semente de tomate cereja desenvolvida pela empresa, totalmente livre de qualquer tipo de insumo proibido à produção orgânica.

Ainda sobre esses aspectos relacionados à qualidade do produto, também foram citados pelos entrevistados, os estudos feitos em busca do conhecimento das necessidades nutricionais de cada espécie plantada e, para essa nutrição, a produção do insumo pela própria empresa. Essas mudanças trouxeram resultados positivos tanto à qualidade do insumo orgânico utilizado na produção quanto à qualidade do produto final.

Inovações na produção agrícola: Dentre as decisões tomadas pela empresa em busca da superação das dificuldades encontradas em seu processo produtivo, percebe-se que algumas destas podem ser consideradas ações inovadoras, que trouxeram, como resultado, o crescimento da atividade produtiva da empresa. Exemplo disso é o conjunto de técnicas implementadas nas quatro etapas de melhorias da produção, consideradas inovações no que tange ao desenvolvimento (ou utilização) de novos processos produtivos pela empresa.

Com relação ao tipo de inovação implementada, pode-se considerar que foram mudanças incrementais, como um processo contínuo de melhoramentos e técnicas ou mesmo "fazer o que fazemos melhor" (TIDD; BESSANT; PAVITT, 2008). Segundo esses mesmos autores, essas mudanças incrementais são capazes de garantir maiores ganhos cumulativos de eficiência no longo prazo do que as mudanças radicais ocasionais.

Nesse sentido, é possível afirmar que essas inovações tiveram fundamental importância para o desenvolvimento da organização, pois, conforme Motta (1998, p. 140), este é "fruto da introdução moderada e constante de novidades", o que pode favorecer o crescimento, de forma evolucionária e progressiva.

Pode-se observar, também, que todas as decisões tomadas em relação à melhoria do processo produtivo agrícola da Fazenda Malunga, corroboram com as noções de inovação 
voltada à sustentabilidade e à não degradação do meio-ambiente, conforme idéias dos autores Bessant e Tidd (2009).

Estes mesmos autores consideram que a inovação pode fazer parte da solução para muitas questões ambientais, algumas delas presentes na empresa estudada, como por exemplo produtos e processos que causam menor impacto ambiental, as chamadas tecnologias limpas, além de processos que visam à redução de resíduos ou uso mais eficiente dos insumos.

Pode-se notar, utilizando tipologia de inovações sustentáveis de Bessant e Tidd (2009), uma predominância da inovação concentrada na melhoria de tecnologias, produtos e serviços já existentes.

A seguir, serão detalhadas as ações implementadas pela empresa com o objetivo de superar as dificuldades encontradas em seu processo produtivo, conforme resumo apresentado no Quadro 4.1.

\subsubsection{Uso de Indicadores para a Análise da Gestão do Produto}

Essa técnica gerencial tem como objetivo a análise da produção do seu ponto de vista comercial, ou seja, busca-se a interação entre a produção e a comercialização, por meio da análise de indicadores como a margem de lucro do produto, a sua aceitação no mercado, a possibilidade de crescimento das vendas e o posicionamento do produto, para que a produção possa ser alterada em função da análise de aspectos gerenciais, sugerindo aumento da produção de certo produto, diminuição, ou até mesmo retirada do mercado.

Dessa forma, pode-se planejar a produção de forma a privilegiar os produtos mais procurados ou os que possibilitem maiores ganhos, a fim de se obter maior eficácia em sua produção.

Sobre esse aspecto é importante enfatizar, de acordo com a literatura, que tem se buscado na produção rural a utilização, não só de ferramentas relacionadas aos aspectos técnicos de seu negócio, mas também voltados à gestão, como uma forma de mudança de postura do produtor rural frente ao mercado. 


\subsubsection{Implementação de Melhorias na Produção em Quatro Etapas}

A contratação de consultoria externa para a produção orgânica da Fazenda Malunga foi essencial para o aumento da produtividade da empresa. Esse trabalho, que teve início há cerca de cinco anos, ainda não terminou e, conforme informação do consultor entrevistado, constitui-se de quatro grandes etapas, todas estas contendo inovações em produção orgânica.

Cada uma dessas etapas, no momento de sua implantação, enfrentou resistência no que tange à mudança de cultura por parte dos funcionários, habituados às técnicas já disponíveis na fazenda, e somente com muita conversa e treinamento, puderam ser plenamente adotadas e trouxeram resultados bastante positivos à empresa.

As quatro etapas de melhoria na produção são as seguintes:

\section{Primeira Etapa de Mudanças na Produção:}

Divisão do trabalho por culturas: essa mudança foi implementada no ano de 2004 e foi a primeira grande mudança proposta pelo Consultor, que se traduziu em uma alteração radical no modo em que se dava a divisão do trabalho na produção agrícola da Fazenda Malunga.

A divisão do trabalho, que antes era feita por tarefas, ou seja, cada funcionário responsável por uma tarefa específica em alguma etapa da produção agrícola, tinha como conseqüência o menor comprometimento do funcionário com relação ao resultado final da colheita, ou seja, este se considerava responsável "pela tarefa" e não tinha a noção exata de sua contribuição para o "todo".

A partir da divisão do trabalho por culturas, ou seja, cada equipe especializada e responsável por determinada cultura, por exemplo, pela alface americana, passou a permitir um maior envolvimento do funcionário com o resultado de seu trabalho, com o "todo" que lhe cabia, ou seja, com a cultura de alface americana, conforme exemplo mencionado.

Cobertura do solo com plástico: esta técnica, que foi implementada na Fazenda Malunga em 2006, consiste na colocação de plásticos nas linhas de plantações, com o objetivo 
de proteger as culturas contra pragas vegetais e animais, evitar a perda de água por infiltração no solo e evitar a lixiviação do adubo em épocas de chuvas, além de diminuir a incidência de doenças, já que as folhas das plantas não têm contato direto com o solo. Abaixo, a Figura 4.1 ilustra essa técnica utilizada na produção.

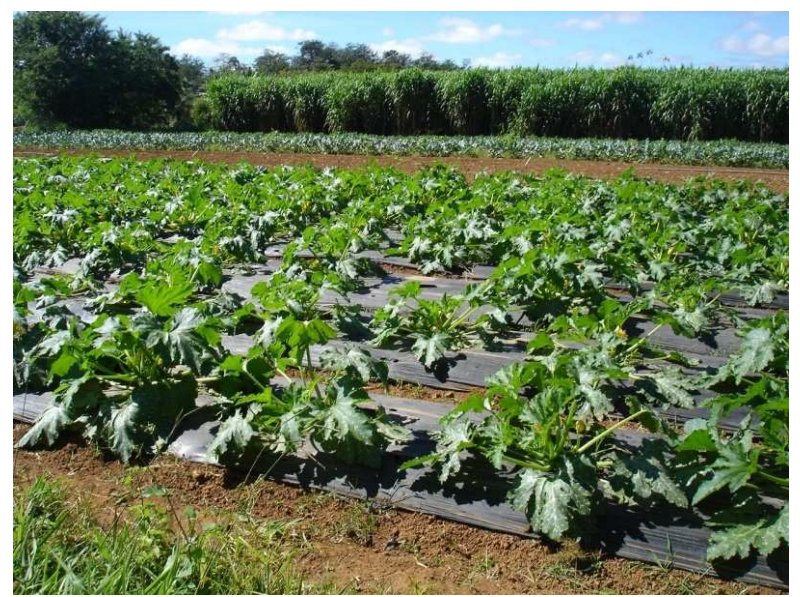

Figura 4.1 - Uso do plástico na cobertura do solo na Fazenda Malunga Fonte: Dados de pesquisa, maio de 2009

Essa técnica empregada, apesar de ter seus resultados comprovados, e até mesmo percebidos pela Fazenda Malunga, em princípio, encontrou muita resistência por parte, tanto dos funcionários, como pelos proprietários da empresa, que consideravam de alto custo, principalmente um dos componentes de fixação do plástico, um gancho de arame associado a um pedaço de madeira cujo preço tornava quase inviável a aplicação efetiva da técnica, que foi feita, inicialmente sem a utilização do gancho. A reintrodução do gancho somente foi possível na quarta etapa dos trabalhos do consultor.

Além dessas técnicas, ainda nessa primeira etapa, foram introduzidas as técnicas de Bokashi e fabricação de Biofertilizantes, que serão mais bem desenvolvidas em momento próprio, pois são consideradas inovações importantes relacionadas ao acesso aos insumos produtivos.

\section{Segunda Etapa de Mudanças na Produção:}

Rotação planejada de culturas: essa técnica, que tem como enfoque a visão sistêmica do processo produtivo, busca na sequiencia lógica e planejada de culturas, obter um 
melhor aproveitamento dos resíduos nutritivos de uma cultura à outra, aumentando a eficiência do uso de fertilizantes e adubos, levando a uma considerável economia de insumos.

A técnica tem como fundamento o conhecimento da necessidade nutricional de cada planta, a fim de que a rotação de culturas inicie-se sempre por aquela espécie com maior exigência de nutrientes, até chegar à espécie cuja necessidade de insumos é menor. Dessa forma, há o aproveitamento de resíduos dos insumos aplicados numa cultura que podem ser utilizados na próxima espécie a ser cultivada.

Um exemplo dado pelo entrevistado é a rotação das culturas começando pela alface, espécie que requer uma quantidade maior de insumos, passando depois ao plantio do brócolis, depois da cenoura, chegando, finalmente, à cultura do adubo verde, que é uma planta reestruturadora do solo. O sistema, nesse caso, pode ser renovado uma vez por ano.

Os objetivos dessa técnica são, dentre outros, a utilização eficiente dos fertilizantes, ou seja, o aproveitamento residual da adubação por outras culturas, e também maior sanidade e qualidade do produto e otimização de recursos.

\section{Terceira Etapa de Mudanças na Produção:}

Essa etapa, apesar de ter como característica uma pequena mudança no processo produtivo, trouxe um grande impacto no rendimento da mão-de-obra.

Reintrodução do gancho na cobertura do solo com plástico: após estudos realizados na fabricação do gancho utilizado para afixação do plástico às culturas, chegou-se a um produto melhor, que dispensa o uso de madeira, a um custo substancialmente menor, o que possibilitou a efetiva utilização da técnica pela Fazenda Malunga, com ganho de tempo de uso do plástico e, portanto, menores custos.

O resultado dessa reintrodução trouxe uma grande economia no uso do plástico, pois afixação deste com o gancho permite a reutilização do plástico de quatro a cinco vezes, contra uma ou duas vezes, quando utilizado sem a afixação com gancho. Além do ganho do tempo necessário para se retirar o plástico, que sem gancho, tinha partes enterradas na terra, o que dificultava sua retirada. 


\section{Quarta Etapa de Mudanças na Produção:}

Irrigação por gotejamento: irrigação de algumas culturas, que antes era feita apenas por aspersão, em que a água é bombeada sob pressão e espalhada sobre as culturas, em deixando as plantas úmidas e, na maioria das vezes, acarretando o escoamento de água e nutrientes importantes. Pelo gotejamento, a água é vagarosamente fornecida a partes específicas da planta por gotejadores, sendo mais bem controlável.

Além disso, essa técnica permite que o uso de caldas de biofertilizantes seja feito pelo mesmo sistema de gotejamento, promovendo uma adubação mais precisa, ao contrário da técnica de pulverização, que requer maior utilização de mão-de-obra, já que as fases de pulverização e irrigação estariam separadas.

Essa nova técnica foi introduzida no ano de 2009 e já possui resultados mensurados, como redução de mão-de-obra no seu manejo, maior eficiência no uso da água, da ordem de $90 \%$, enquanto a aspersão tinha como eficiência o percentual de $75 \%$, além de economia de energia, no gotejamento, por volta de $50 \%$.

\subsubsection{Estudos Relacionados à Necessidade Nutricional de Cada Espécie}

Conhecer os nutrientes necessários ao cultivo de cada planta, além de possibilitar a economia de insumos, conforme citado na segunda etapa, possibilita a obtenção de melhores resultados na qualidade do produto.

Saber a quantidade exata de insumos a ser oferecida à planta, de maneira a atender todas as suas necessidades, facilita na obtenção de produtos mais vistosos, saborosos e saudáveis.

Esse conhecimento na Fazenda Malunga, somente foi possível a partir de muitos estudos, além de viagens do proprietário a vários países, cuja experiência em cultivo de orgânicos é maior do que a brasileira como, por exemplo, Austrália e Alemanha, além de busca de informações na literatura disponível.

Mas esse conhecimento teórico somente gerou bons resultados após ser colocado em prática na Fazenda Malunga, e adaptado às particularidades da propriedade, como clima e tipo de solo, por exemplo. 
Para isso, muitos experimentos foram realizados em solo próprio, normalmente iniciados em pequena proporção, que muitas vezes resultaram em fracassos e perdas de produção, mas também proporcionaram aperfeiçoamentos que levaram à produção de várias espécies com maior qualidade.

\subsubsection{Fabricação de Insumo Próprio}

Conforme já mencionado, devido à dificuldade de encontrar insumos, como adubos e fertilizantes orgânicos, no mercado do Distrito Federal, a empresa, por meio de pesquisas e experimentações, passou a desenvolver seus próprios insumos. Dessa forma, as composições podem ser "customizadas" às necessidades de cada espécie. As técnicas a seguir mencionadas também foram introduzidas a partir da consultoria contratada pela empresa.

Atualmente a empresa utiliza a técnica do Bokashi, que é um composto de elementos fertilizantes, no qual se utilizam torta de mamona, rochas e farelos, como o de milho e o de arroz, que fermentam, por no mínimo 15 dias, até serem utilizados na lavoura.

Além do Bokashi, a empresa desenvolve caldas fertiprotetoras, ou biofertilizantes, insumos bastante utilizados na agricultura orgânica, que são pulverizados na plantação ou injetados na água da irrigação por gotejamento, com bons resultados na proteção contra pragas e doenças. A Figura 4.2, abaixo, ilustra o processo de fabricação desse insumo.

Figura 4.2 - Fabricação de biofertilizantes na Fazenda Malunga

Fonte: Dados de pesquisa, maio de 2009. 
Outro ponto a ser destacado é a mudança na preparação da compostagem, antes feita manualmente e agora, com o uso de máquinas. A compostagem é uma técnica de controle da decomposição de materiais orgânicos, a fim de se obter material estável e rico em húmus e nutrientes minerais. A mecanização dessa atividade trouxe melhor aproveitamento da mão-deobra, haja vista a atividade poder ser realizada com menos pessoas. A Figura 4.3 ilustra o pátio de compostagem existente na sede da empresa.

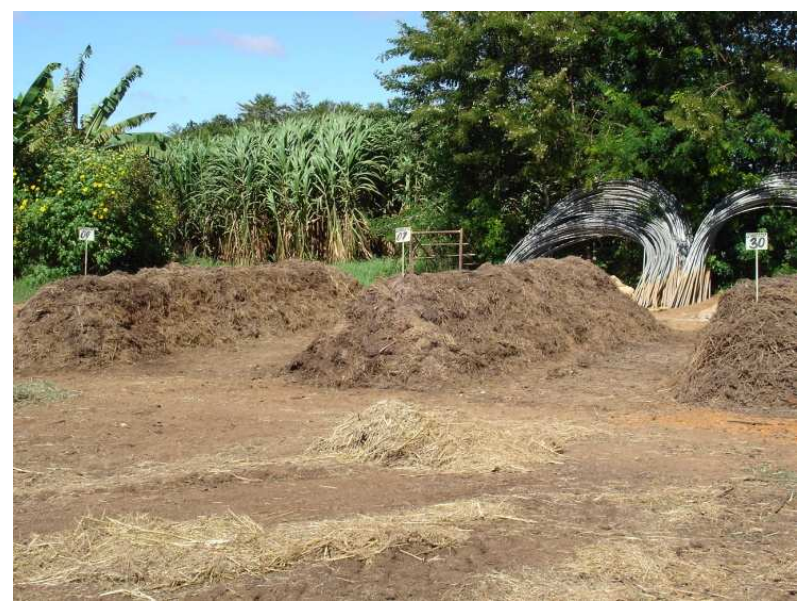

Figura 4.3 - Pátio de compostagem da Fazenda Malunga Fonte: Dados de pesquisa, maio de 2009.

\subsubsection{Dificuldades Relacionadas à Produção Agrícola Atual}

Em resposta às perguntas formuladas, os entrevistados forneceram alguns dados relacionados às principais dificuldades enfrentadas no atual processo produtivo da empresa, como pode ser observado no Quadro 4.2:

\section{Principais dificuldades encontradas atualmente}

- Esgotamento da capacidade produtiva da propriedade da empresa

- Necessidade de aquisição de produtos de outros estados para manutenção da regularidade do fornecimento

\section{Possíveis soluções apontadas pelos entrevistados}

- Aquisição de novas terras e/ou parcerias com produtores locais

- Implementação de novas técnicas produtivas que possibilitem o plantio regular, mesmo em condições climáticas adversas 
Apesar de o aprofundamento dessas questões mais atuais não ser objeto desse estudo de caso, alguns comentários podem ser feitos a respeito do momento vivido pela empresa, no que tange à sua produção.

Um desafio apontado pela empresa é o esgotamento da capacidade produtiva da propriedade, ou seja, não há mais espaço para expansão da produção na propriedade atual, o que impele a empresa a buscar novas terras e/ou buscar parcerias com outros produtores locais.

A respeito das parcerias, a empresa tem consciência de que estas devem acontecer de maneira planejada, sob a forma de estímulos a pequenos produtores a fim de que preparem suas terras para o plantio orgânico e para a certificação.

A empresa reconhece também que possui um know-how muito desenvolvido a respeito da produção e da distribuição de hortaliças, o que, em princípio, sugere que as parcerias devam iniciar na produção de frutas e verduras.

Outra dificuldade advinda do esgotamento da capacidade produtiva é a necessidade de aquisição de produtos orgânicos de outros estados do país, como, por exemplo, cebola do Rio Grande do Sul, conforme ilustra a Figura 4.4 abaixo, a fim de que o fornecimento regular seja mantido.

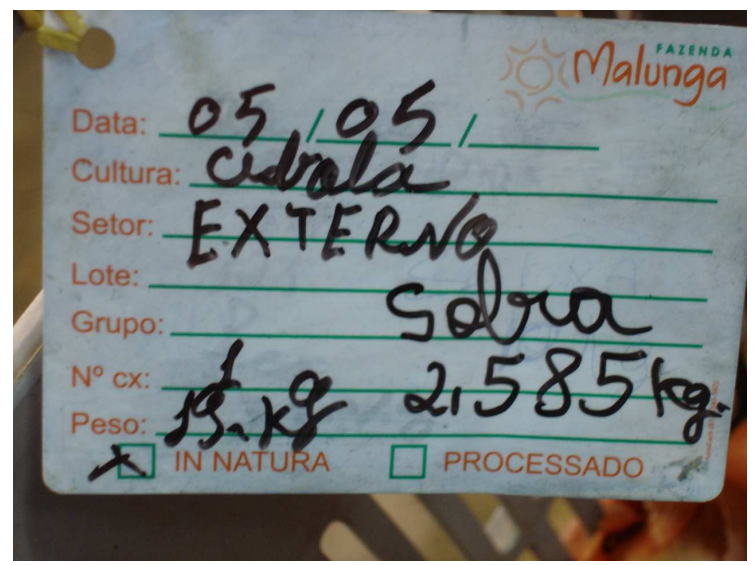

Figura 4.4 - Produtos de outros estados brasileiros garantem o fornecimento regular. Fonte: Dados de pesquisa, maio de 2009 


\subsection{Superação de Obstáculos e Inovações no Processamento Pós-Colheita}

Para os fins do presente trabalho, é possível considerar que o incremento do processamento da produção foi a maior inovação da empresa a fim de aumentar seu mix de produtos e obter maior lucratividade. O processamento da produção permitiu o desenvolvimento de novos produtos, o que permitiu atingir um público novo, diferenciado, que busca maior comodidade e praticidade, no que tange ao consumo de produtos agrícolas.

\subsubsection{Produtos Minimamente Processados: Agregação de Valor}

A inclusão no mercado dos produtos minimamente processados permitiu à empresa agregar valor a seus produtos e, com isso, obter maiores margens de lucro se comparado ao produto in-natura. A Figura 4.5, abaixo, ilustra dois produtos minimamente processados pela empresa, quais sejam, Alface Americana Orgânica Higienizada e Salada Candanga Orgânica Higienizada, esta última composta por alface americana, alface lisa e cenoura em tiras.
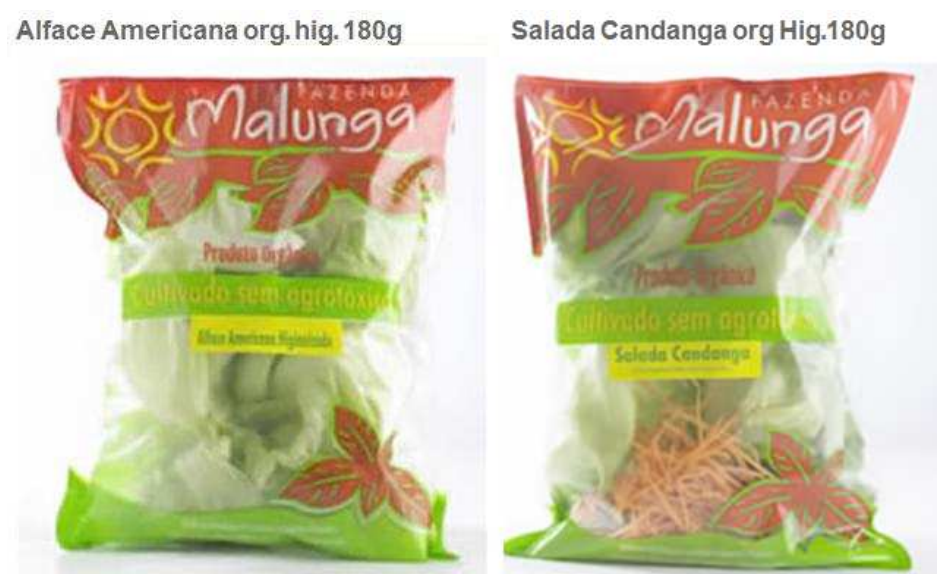

Figura 4.5 - Produtos minimamente processados: Alface Americana Orgânica Higienizada e Salada Candanga Orgânica Higienizada.

Fonte: www.malunga.com.br. Acesso em 13 jun 2009.

Esse tipo de produto, conforme Zuin (2004 apud ZUIN, 2006), pode ser classificado como um bem especial agroalimentar, que se diferencia das chamadas commodities por passar 
por algum tipo de transformação, mínima ou total, e ainda possuir, nesse caso, uma certificação (de produto orgânico).

Os produtos minimamente processados podem ser considerados, conforme Lopes e Nantes (2006), como o resultado da modernização do produtor rural em resposta ao aumento da concorrência e à disputa por novos e melhores mercados.

Essa inovação também está associada a uma nova necessidade advinda com os estilos de vida das pessoas que, conforme Beaulieu et al (1997, apud SOARES, 2002), têm menos tempo para a preparação dos alimentos e preferem produtos como frutas e verduras minimamente processados.

Sabe-se, no entanto, que esse tipo de produto, conforme Nantes e Leonelli (2000), reduz a vida útil da matéria-prima, sendo de difícil produção. Considerando esse aspecto, pode-se dizer que o processamento da pós-colheita, talvez seja uma das áreas mais críticas da empresa no momento atual, que ainda carece de aperfeiçoamentos quanto aos seus processos e gestão, principalmente.

A primeira concepção da empresa a respeito dos produtos processados era de que este derivaria do aproveitamento das "sobras" da produção in-natura, mas isso durou pouco tempo: devido à aceitação do produto no mercado, percebeu-se que seria necessário produzir algumas espécies direcionadas ao processamento.

A empresa possui um mix de produtos bastante variado, como por exemplo, cenoura ralada, couve picada, saladas prontas (Dois Amores, Três Amores, Quatro Amores, Primavera, Candanga, Cristina), dentre outros.

Mas nem todos os produtos processados tiveram boa aceitação pelo mercado e, por isso, alguns tiveram de ser retirados das prateleiras como, por exemplo, a sopa de bebê, a salada frisé, a salada romana, o repolho e a beterraba picados e a cenoura em cubos.

As principais dificuldades encontradas no processamento pós-colheita hoje estão ligadas à infra-estrutura do barracão destinado ao processamento da colheita, pois é pequeno e tem leiaute inadequado ao processo, além da falta de equipamentos.

Outra dificuldade reside em encontrar mão-de-obra para os serviços de processamento e capacitação dessa mão-de-obra, já que esse processo requer habilidade e técnicas específicas de higiene, principalmente quanto à perecibilidade dos produtos. 
Outro aspecto relacionado à higiene e que é de difícil adaptação é a adequação do processamento às rígidas normas da Vigilância Sanitária, principalmente por hoje não existir legislação específica para a higienização de produtos processados orgânicos no Distrito Federal.

Mas talvez a maior dificuldade relacionada ao processamento esteja relacionada à falta de indicadores, e parâmetros de gestão dessa produção, que poderiam levar à otimização dos resultados, aspecto bastante desenvolvido no processo produtivo da Fazenda Malunga, mas ainda não empregado efetivamente no processamento pós-colheita.

\subsection{Superação de Obstáculos e Inovações na Comercialização}

A comercialização dos produtos da Fazenda Malunga começou, há cerca de 15 anos, principalmente, por meio da venda direta em feiras de produtos orgânicos, pelo delivery (a entrega de produtos em domicílios) e por visitas guiadas à Fazenda, sob a forma de Agroturismo.

Mas essas formas de comercialização sozinhas não foram suficientes para garantir a sustentabilidade da empresa, uma vez que trouxeram algumas dificuldades, como por exemplo, as feiras orgânicas, que por terem como participantes vários produtores rurais, não garantem que toda a mercadoria seja vendida por todos.

Para fins de ilustração, se for uma época propícia ao plantio de cenouras, e todos os produtores levarem muita cenoura para ser vendida na feira, possivelmente, haverá cenouras não comercializadas. Já a entrega em domicílios, além de bastante trabalhosa em função da organização da logística, é uma atividade arriscada quanto ao recebimento pela venda, já que existem clientes habituais que compram "fiado", além de ser difícil aumentar o número de clientes, de forma que todos os produtos produzidos sejam comercializados.

A seguir são apresentadas, no Quadro 4.3, as principais dificuldades (ou obstáculos) relacionadas à comercialização dos produtos Malunga, seguido das formas encontradas pela empresa para superá-las. 


\begin{tabular}{|l|l|l|}
\hline \multicolumn{2}{|c|}{ Principais obstáculos } & \multicolumn{2}{c|}{ Como foram superados } \\
\hline $\begin{array}{l}\text { Necessidade de organização e controle dos } \\
\text { produtos vendidos em supermercados }\end{array}$ & $\bullet$ Promotores próprios em supermercados \\
\hline $\begin{array}{l}\text { Aumento do número de clientes de } \\
\text { produtos orgânicos }\end{array}$ & $\bullet$ Aperfeiçoamento das visitas guiadas \\
\hline - Aumento das vendas em domicílio & $\begin{array}{l}\text { - Venda por internet } \\
\text { - Contato pró-ativo de telemarketing }\end{array}$ \\
\hline - Organização da distribuição & - Compra de caminhão e organização da \\
& \multicolumn{2}{l|}{ logística } \\
\hline
\end{tabular}

Quadro 4.3 - Superação de obstáculos em comercialização pela Fazenda Malunga

Fonte: Dados de pesquisa, elaborado pela autora, junho 2009.

A fim de aumentar a quantidade de produtos comercializados, há cerca de 10 anos a empresa passou a vender também a supermercados da cidade, e esse processo sofreu aperfeiçoamento nos últimos cinco anos, por meio da introdução de promotores.

Já as visitas guiadas, citadas anteriormente, mais do que a venda, objetivam levar os clientes ou potenciais clientes à sede da empresa, para que possam conhecer o processo produtivo orgânico, a filosofia que envolve sua produção, além do contato com a natureza local.

Além disso, foi introduzido um novo canal de vendas, o sítio da empresa na internet, canal hoje bastante utilizado na venda a domicílio.

Inovações na comercialização: a postura estratégica da empresa relacionada à comercialização corrobora com a idéia de Oliveira (2006), relacionada à Estratégia de Desenvolvimento, em que a organização busca o seu desenvolvimento por meio da procura por novos mercados e clientes, diferentes do que é habituado. No caso estudado, a empresa inovou com canais de vendas incomuns ao Agronegócio, como é o caso da venda por internet.

Mas essa postura também está alinhada à idéia de inovação em busca de maior competitividade no mercado, conforme Fiates (1997, apud FIATES; FIATES, 2008). A utilização do canal de vendas pela internet, a utilização da visita guiada à empresa (ou Agroturismo) como forma de atrair novos clientes, ou mesmo a introdução de promotores de vendas em supermercados, podem ser consideradas importantes inovações no que tange ao atingimento de novos mercados e, portanto, de novos clientes. 
A seguir, as idéias apresentadas no Quadro 4.3 serão detalhadas, para melhor entendimento das mudanças implementadas pela empresa.

\subsubsection{Contratação de Promotores para Atuação em Supermercados}

A Fazenda Malunga fornece produtos para mais de 40 supermercados do Distrito Federal, sendo esta sua maior fonte de faturamento. Para auxiliar nesse processo, a empresa contratou um contingente de promotores na proporção de quase um promotor por supermercado atendido. Apenas os mercados menores possuem promotores que se dividem entre dois ou mais estabelecimentos.

Os promotores de vendas nas lojas, além de executarem tarefas de controle de estoque, organização de prateleiras e gôndolas, são capazes de aferir a correta disposição do produto quanto à temperatura a que são expostos, além de terem uma função essencial de contato direto com o cliente.

Um problema apontado na venda a supermercados é o risco do enfraquecimento da marca, haja vista que nos produtos vendidos às principais redes de revenda, o grupo Pão de Açúcar e o Grupo Carrefour, as suas embalagens têm a marca Malunga substituídas pelas marcas Taeq e Viver, bandeiras dos dois supermercadistas.

A presença dos promotores de venda da Fazenda Malunga nos supermercados, apesar de não ser suficiente para isso, tenta amenizar a questão relacionada ao enfraquecimento da marca, por meio da abordagem de clientes, com degustações de outros produtos que permanecem com o nome Malunga, e também com a informação de que "aqueles produtos Taeq ou Viver", foram produzidos na Fazenda Malunga.

A inclusão de promotores em supermercados é apontada como sendo de tão importante avanço, que foi citado, por um dos entrevistados, o fato de outras empresas de orgânicos do Distrito Federal não conseguirem sucesso nas vendas nesse canal, por não oferecerem esse diferencial. 


\subsubsection{Aperfeiçoamento das Visitas Guiadas}

As visitas à propriedade da empresa, apesar de acontecerem desde o início da abertura da empresa, sofreram aperfeiçoamentos nos últimos anos, o que permitiu o aumento do número de visitantes, chegando a 1.500 pessoas anualmente.

Para que esse resultado fosse possível, a infra-estrutura da fazenda foi modificada, tendo sido construídos um restaurante, no qual são fornecidos, além da alimentação diária aos funcionários, café da manhã e almoço orgânicos aos visitantes, incluídos no preço da visita, atualmente $\mathrm{R} \$ 25,00$ por adulto, e ainda uma sala de aula, para palestras.

No roteiro da visita, que inicia às 8 horas da manhã, saindo da Praça dos Três Poderes, em Brasília, estão incluídos, além da alimentação já citada, palestras com funcionários e proprietários a respeito da produção orgânica, além da filosofia que envolve a produção de orgânicos, e ainda um tour pela fazenda. Abaixo, a Figura 4.6, ilustra uma das últimas visitas guiadas a empresa, no primeiro semestre de 2009:

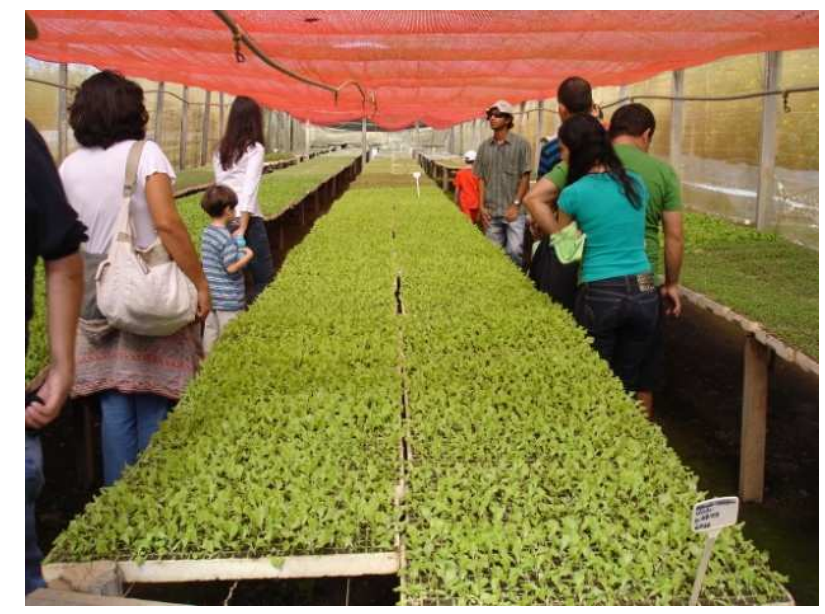

Figura 4.6 - Visita à Fazenda Malunga em 24/05/2009

Fonte: Dados de pesquisa, maio de 2009

Além de buscar o aumento e a fidelização dos clientes, essas visitas objetivam o contato direto com estes, que são estimulados a opinar, sugerir melhorias aos produtos, sugerir novos produtos e fazer eventuais reclamações.

Apesar de os resultados não serem mensurados, acredita-se que as visitas guiadas, que têm aumentado em freqüência e número de pessoas a cada ano, seja um importante meio 
de fortalecimento e consolidação da empresa no mercado, pois acredita-se que o resultado das visitas é bastante positivo.

\subsubsection{Vendas por internet}

Há cerca de quatro anos, a venda de produtos orgânicos voltados para entrega a domicílio recebeu um reforço importante: a possibilidade de os pedidos serem feitos pela internet, por meio do sítio da empresa www.malunga.com.br.

A figura 4.7 ilustra a página inicial do sítio da empresa na internet:
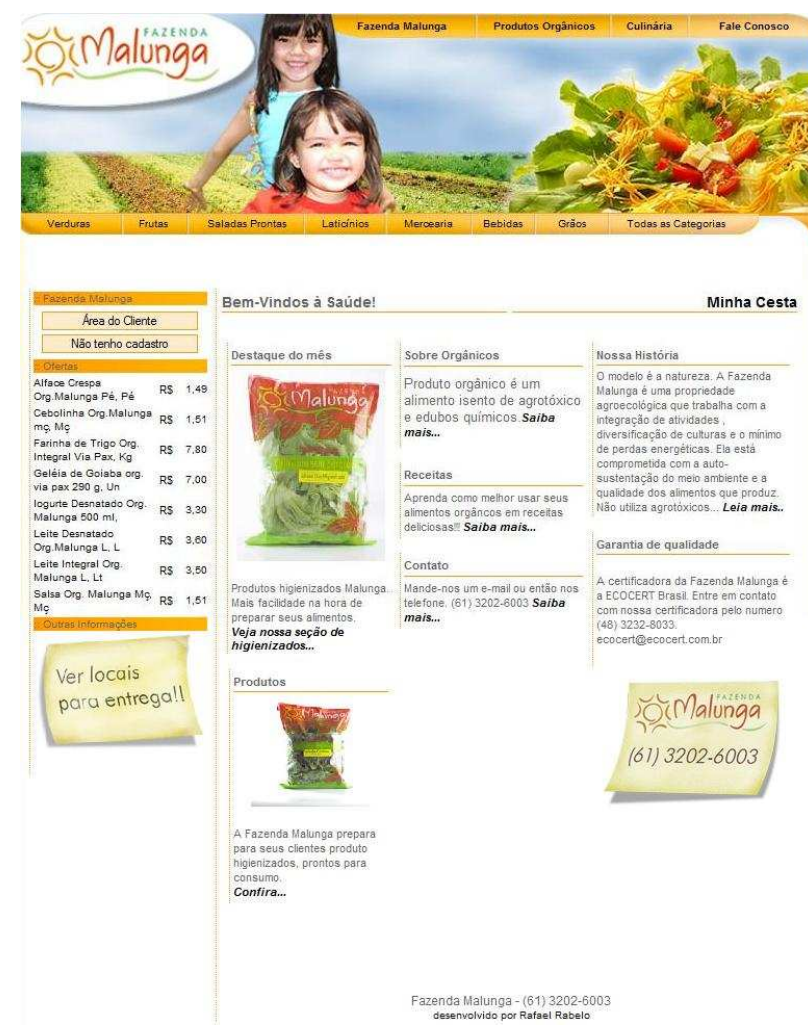

Figura 4.7 - Página inicial do sítio da empresa Fazenda Malunga na internet Fonte: www.malunga.com.br. Acesso em 13 jun 2009

Além da facilidade oferecida aos clientes, que têm a possibilidade de navegar pela página da empresa, ver fotos dos produtos, saber quais estão disponíveis para aquele dia, conhecerem os locais e horários de entrega disponíveis para sua casa, a empresa consegue também controlar melhor suas vendas e organizar as entregas com maior eficiência, além de ter mais um canal para efetivar vendas a domicílio, além do telefone. 
O sítio na internet fornece ainda informações sobre produtos orgânicos e a história da empresa, além de fornecer o nome e contato da empresa certificadora, a Ecocert. É possível encontrar também receitas e dicas de alimentação saudável, proposta principal da organização.

Após efetivar um cadastro na chamada área do cliente, em que são solicitados dados como nome, e-mail, senha para acesso, dados de restrição alimentar, horário preferível para entregas, endereço para entregas, dentre outros, o cliente está apto a efetuar suas compras.

Uma vez composta a "cesta de produtos" e efetuada a compra virtual, um e-mail é enviado ao cliente, confirmando os produtos escolhidos, conforme ilustra a Figura 4.8:

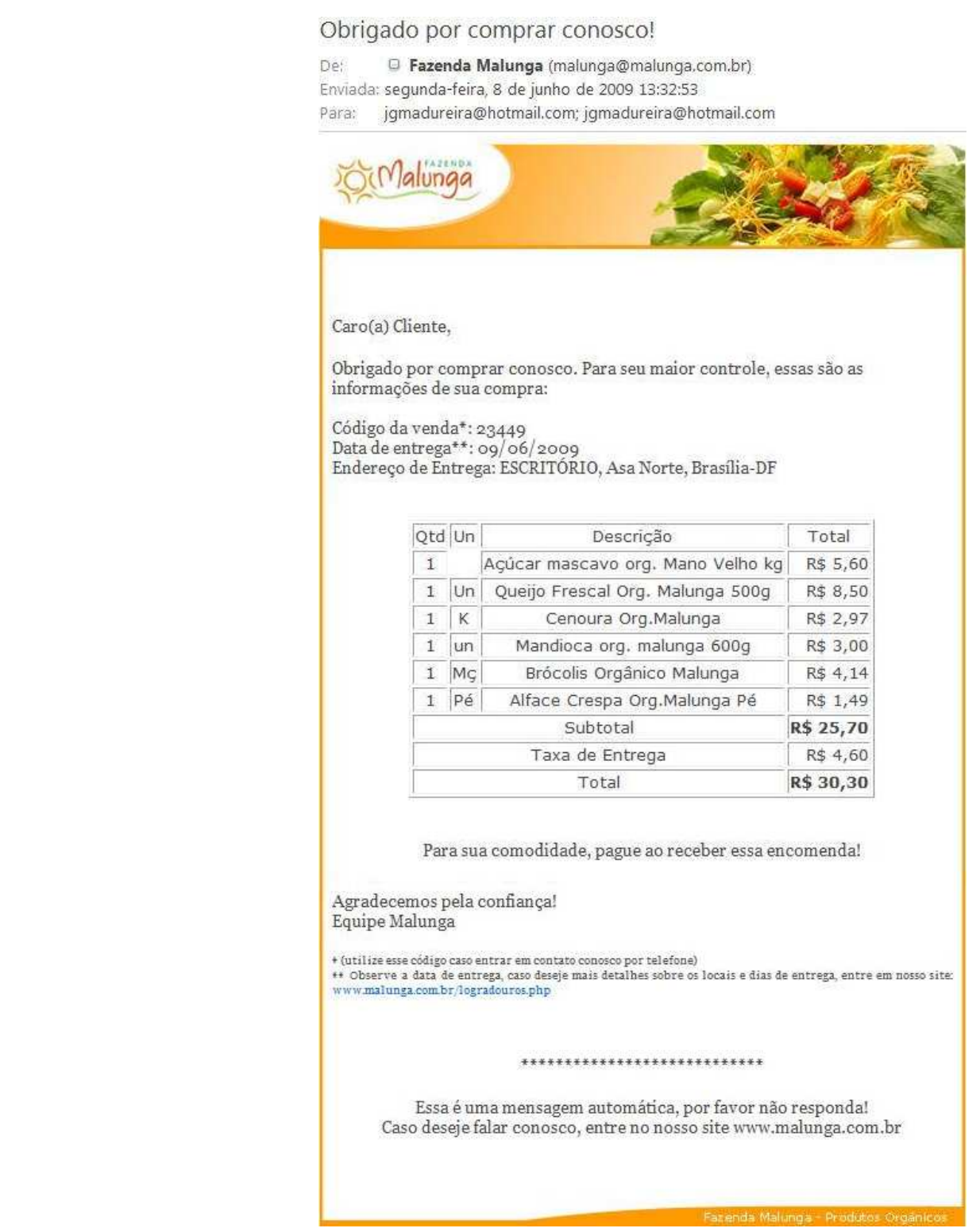

Figura 4.8 - Confirmação de compra por e-mail

Fonte: e-mail da autora, recebido em 08 jun 2009 


\subsubsection{Contato Pró-Ativo de Telemarketing}

A empresa, por meio de telefone, faz contato direto com alguns clientes habituais, para que estes possam efetivar seu pedido semanal.

Apesar de não ser um serviço oferecido em larga escala, permite maior fidelização de clientes, que se sentem privilegiados ao serem contatados para receber informações a respeito de promoções, ou somente para que possam garantir o recebimento de sua compra habitual.

\subsubsection{Compra de Caminhão e Organização da Logística de Distribuição}

Para viabilizar o correto escoamento de sua produção, quais sejam, a entrega diária em supermercados e entrega destinada às vendas em domicílio (que são repassadas a motoboy), a empresa precisou investir na compra de um caminhão, no qual fosse possível a adequação para acomodação e refrigeração dos produtos a serem vendidos.

Para alcançar o objetivo de fazer entregas com manutenção da qualidade dos produtos da fazenda até seu destino final, a empresa também estudou maneiras de otimizar sua logística de distribuição, que começa no momento da colheita.

Produtos como as hortaliças, por exemplo, que precisam ser entregues sempre fresquinhas e vistosas, necessitam de técnicas e timming certos para colheita e distribuição, sob pena de não mais serem vendidos, por sua aparência não aprazível e qualidade inferior.

A colheita das hortaliças acontece sempre no fim da tarde ou início da noite (dependendo da época do ano) e estas são, logo em seguida, empacotadas e seguem de caminhão durante a madrugada, diretamente aos supermercados.

A qualidade percebida dos FLVs (área dos mercados destinada a frutas, legumes e verduras) orgânicos no mercado do Distrito Federal é bastante superior ao mercado de São Paulo, por exemplo, conforme informação da proprietária entrevistada. Para se ter um idéia, em São Paulo, os produtos orgânicos ocupam apenas 4\% dos FLVs, enquanto no Distrito Federal, a área destinada a orgânicos chega a 10\%, segundo a entrevistada.

Um dos motivos que favorecem essa diferença é a maior facilidade logística encontrada no Distrito Federal, ou seja, por ser uma capital de menor extensão, o tempo entre 
a colheita e a entrega aos mercados é, naturalmente, menor, desde que os fornecedores aproveitem essa vantagem.

E é o que faz a Fazenda Malunga. Sua logística é organizada de forma a coordenar a colheita com o empacotamento e a distribuição, para que os produtos orgânicos fornecidos aos mercados, além de mais saudáveis, sejam ainda mais frescos, vistosos e atrativos que os produtos advindos da agricultura convencional que, normalmente, saem da fazenda do produtor rural para o Ceasa (no caso do DF) e do Ceasa para os supermercados, aumentando assim, seu tempo de armazenamento e transporte, antes de chegar ao consumidor final.

\subsubsection{Dificuldades Relacionadas à Comercialização Atualmente}

Algumas dificuldades relacionadas à comercialização atualmente, conforme brevemente mencionadas, e identificadas pelo Quadro 4.4 abaixo:

\section{Principais dificuldades encontradas atualmente}

- Aumento da capacidade produtiva

- Aumento da venda a supermercados X enfraquecimento da marca

\section{Possíveis soluções apontadas pelos entrevistados}

- Busca de parcerias

- Possibilidade de abertura de um mercado próprio

Quadro 4.4 - Principais dificuldades encontradas em comercialização atualmente

Fonte: Dados de pesquisa, elaborado pela autora, junho de 2009

Assim como a dificuldade que permeia o processo produtivo, o esgotamento da capacidade produtiva da propriedade atual da empresa, inviabiliza ações imediatas para o aumento das vendas.

Para se ter uma idéia, a Fazenda Malunga fornece a supermercados atualmente, somente $30 \%$ da demanda desse canal, ou seja, existe um potencial grande de crescimento do fornecimento a supermercados, inviabilizado pela não capacidade produtiva.

O aumento das vendas a domicílio também não pode ser encorajado, a princípio, devido ao mesmo fator apontado. 
Nesse sentido, as possíveis soluções apontadas pelos entrevistados partem da aquisição de novas terras ou parcerias em produção, e, após essa solução ser implementada, poder-se-ia vislumbrar, ainda que no longo prazo, a aquisição de um mercado próprio de produtos orgânicos para o Distrito Federal.

\subsection{Superação de Obstáculos e Inovações na Gestão Integrada da Empresa}

Conforme entrevista com proprietária da empresa e com uma das funcionárias, gerir a Fazenda Malunga é (e sempre foi) um obstáculo, algo que precisa de ajustes, conhecimento de técnicas de gestão, a fim de se buscar o crescimento sustentável da organização.

A seguir serão apresentadas, no Quadro 4.5, algumas dificuldades sofridas no processo de gestão da empresa e como foram superadas por meio de inovações:

\begin{tabular}{|l|l|}
\hline \multicolumn{1}{|c|}{ Principais obstáculos } & \multicolumn{1}{|c|}{ Como foram superados } \\
\hline - Dificuldades financeiras & • Vendas a supermercados \\
\hline - Gestão tecnológica & • Contratação de consultoria em produção \\
\hline - Obtenção e retenção de mão-de-obra & • Criação do Conselho de Gestão \\
& - Participação nos lucros \\
& - Comissões por produtividade \\
& - Ginástica Laboral / Yoga \\
\hline - Necessidade de maior profissionalização \\
da empresa & - Construção de casas funcionais \\
\hline
\end{tabular}

Quadro 4.5 - Superação de obstáculos em gestão pela Fazenda Malunga

Fonte: Dados de pesquisa, elaborado pela autora, junho de 2009

A empresa Fazenda Malunga já "quebrou”, ou teve grandes fracassos, por três vezes, mas isso não foi suficiente para que a empresa saísse do mercado. Pelo contrário, esses obstáculos, após superados, foram importantes para o aprendizado organizacional, já que a empresa passou a calcular melhor seus passos, a fim de buscar sua permanência e crescimento no mercado.

A Fazenda Malunga tem, por uma particularidade do Distrito Federal, uma grande dificuldade de acesso a crédito. Por ser uma fazenda arrendada do Governo do Distrito Federal, onde ocorre toda a produção agropecuária da empresa, não configura situação 
necessária ao acesso a crédito destinado à produção rural, cujos juros médios são de $7 \%$ anuais.

A situação de arrendamento de terras do GDF é comum a quase $70 \%$ produtores rurais do Distrito Federal, segundo a proprietária, e essa situação tem dificultado o fomento da produção agrícola da região, justamente pela dificuldade de acesso a financiamento agrícola.

Outro aspecto a ser destacado é que, há alguns anos, a empresa passou por um processo de busca pela profissionalização, já que era uma empresa essencialmente familiar, mas com "muitos donos", por conta da forma como foi idealizada por estudantes e pessoas interessadas na produção orgânica.

Inovações na gestão integrada: no processo de agregação de valor ao setor rural, a gestão do negócio, conforme Vilckas e Nantes (2006), apesar de este ser um dos aspectos mais importantes, talvez seja o mais difícil, pois está ligado a fatores não controláveis, como variações climáticas, sazonalidade, perecibilidade de produtos.

Além disso, não há, para o setor rural, um modelo de gestão adequado ao seu negócio. Segundo os autores, isso se deve às diferenças regionais em termos de clima, solo, disponibilidade e capacitação de mão-de-obra, dentre outros.

Vilckas e Nantes (2006) ainda afirmam que a gestão do empreendimento rural é insuficientemente tratada na literatura, e são incipientes os esforços dedicados a ferramentas de gestão do Agronegócio.

Nesse sentido, as ações implementadas na gestão da empresa Fazenda Malunga, em muitos aspectos, como a utilização de ferramentas gerenciais como o Planejamento Estratégico, a utilização de políticas de remuneração, o oferecimento de ginástica laboral, dentre outras, podem ser consideradas como parte de um esforço de implementação de inovações, ainda que incrementais, porém de forma continuada, alinhados à postura estratégica de busca pela competitividade no mercado.

\subsubsection{Vendas a Supermercados}

Há cerca de 10 anos, a Fazenda Malunga aproveitou a oportunidade de vender a grandes supermercados do Distrito Federal. São muitas as vantagens advindas desse tipo de 
venda, dentre elas, o aumento de escala e a segurança oferecida à empresa, que vende por meio de contratos.

Mas para isso, a sede produtiva da empresa teve de ser reestruturada para atender aos requisitos dos supermercados que, inclusive, auditam a propriedade uma vez por ano. Houve mudança no processo produtivo e na forma de processamento dos produtos, a fim de atender esse novo mercado.

Há também especificidades inerentes a cada rede de supermercados. Por exemplo, existem duas grandes redes para as quais a Fazenda Malunga fornece atualmente, a Viver, pertencente à rede Carrefour, e a Taeq, do grupo Pão de Açúcar.

Essas duas redes exigiram que, gradativamente, os produtos Malunga vendidos em suas lojas, fossem identificados com as marcas Taeq e Viver, ou seja, utilização da bandeira das marcas dos supermercados. É visível que o poder de barganha desses fornecedores é muito grande e afeta o dia-a-dia da empresa.

Por outro lado, é inegável a importância do fornecimento a supermercados - hoje mais de 40 estabelecimentos, que oferecem ganho de escala, maior segurança financeira, além da possibilidade de antecipação de recebíveis oferecida pelo grupo Pão de Açúcar.

Devido à dificuldade de crédito já explicada, a empresa utilizou, principalmente no início de seu fornecimento a supermercados, a possibilidade oferecida pelo grupo Pão de Açúcar de antecipação do recebimento pelos produtos vendidos.

O prazo médio de recebimento da empresa é de 50 dias e, com essa possibilidade de antecipação de recebíveis, o que a Malunga fornecia num dia, podia antecipar dois dias depois, mas por um custo cujos juros eram um pouco inferiores à média de financiamentos bancários.

Apesar do custo desse financiamento ser ainda muito superior ao crédito agrícola, a empresa, por não ter acesso a esse tipo de crédito, se valeu da oportunidade oferecida pelo seu fornecedor, o que favoreceu a gestão da empresa por bastante tempo. 


\subsubsection{Gestão Tecnológica}

Conforme está mais bem detalhado no item Produção, deste capítulo de resultados da pesquisa, a contratação de consultoria na área de produção agrícola foi de importante valia para a produtividade agrícola da empresa.

O profissional, que reside em São Paulo, foi contratado há cerca de cinco anos, e faz atualmente duas visitas à empresa por mês. Sua rotina na empresa consiste em trazer técnicas e tecnologias novas, aprimorar as já existentes, controlar as técnicas e tecnologias implementadas, fazer mensuração dos resultados obtidos, além de fornecer treinamentos trimestrais.

Os treinamentos oferecidos pelo consultor são feitos aos funcionários de nível técnico ou engenheiros agrônomos da empresa, que posteriormente repassam o que aprenderam aos líderes de cada área produtiva, que por sua vez, repassam aos demais funcionários. Porém, quando necessário, o consultor vai ao campo e instrui todos os funcionários de forma direta.

A eficiência produtiva percebida pela empresa atualmente foi, em grande parte, advinda da contratação desse profissional, que já implementou mudanças significativas no processo produtivo da empresa, conforme já mencionado.

\subsubsection{Conselho de Gestão e Políticas de Remuneração}

A fim de possuir políticas voltadas à valorização da mão-de-obra, a empresa implementou o que denomina Conselho de Gestão, além da Participação nos Lucros e Comissões por Produtividade.

O Conselho de Gestão é composto por aqueles funcionários que possuem mais de 8 anos de casa e que têm interesse em participar. Esse conselho foi criado com o intuito de oferecer aos funcionários mais antigos da organização, a oportunidade de opinarem, formalmente, em prol do desenvolvimento da empresa. Para isso são realizadas reuniões periódicas, em que os membros do Conselho têm vez e voz para opinar, sugerir, em suma, darem sua contribuição à gestão da empresa. 
Para esses funcionários que compõem o Conselho de Gestão, a empresa destina parte de sua lucratividade em forma de Participação em Lucros, que são distribuídos trimestralmente.

Já para os demais funcionários, que possuem menos tempo de serviço, a empresa oferece Comissões por Produtividade, que são definidas a partir de metas pré-estabelecidas e perseguidas pelos funcionários.

\subsubsection{Ginástica Laboral e Yoga}

Por executarem tarefas repetitivas e, a fim de se evitar lesões aos funcionários, a empresa adotou, há alguns anos, as atividades periódicas de Ginástica Laboral e Yoga, de livre adesão pelos funcionários, cuja maior participação é feita pelas mulheres que trabalham, principalmente, na produção e processamento pós-colheita. A Figura 4.9 ilustra a atividade de ginástica laboral realizada na empresa:

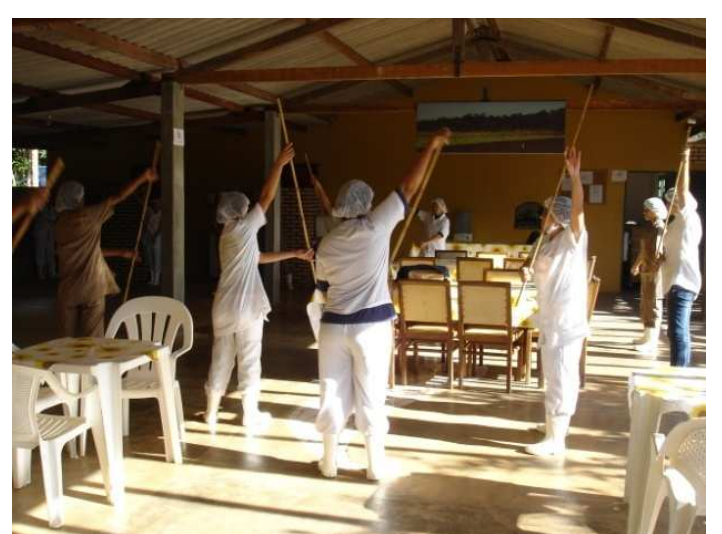

Figura 4.9 - Ginástica Laboral realizada na Fazenda Malunga em 04 jun 2009 Fonte: Dados de pesquisa, junho de 2009

Essas atividades são benéficas, principalmente em se tratando de um momento destinado à saúde dos funcionários. Por conter um grande contingente de mulheres, inclusive algumas grávidas, esses exercícios são importantes para quem os pratica, mas também para a empresa, que se beneficia com a diminuição de atestados médicos por lesões funcionais, por exemplo. 


\subsubsection{Construção de Casas para Funcionários}

Por se localizar há 70 quilômetros da cidade de Brasília, não é difícil deduzir que encontrar mão-de-obra local não é uma tarefa muito fácil. Quanto mais contratar pessoas que residem em Brasília e fornecer transporte diário a estes.

A fim de amenizar esses problemas, a empresa construiu casas em sua propriedade, destinadas a abrigar funcionários que optam por residir na sede da empresa.

Além das casas, há também um alojamento, destinado a estudantes que fazem estágios, principalmente futuros engenheiros agrônomos, que pretendem conhecer um pouco mais sobre a agricultura orgânica, alguns deles sendo até mesmo contratados pela empresa ao final do estágio.

A construção dessas casas foi possibilitada por meio de investimento de muito capital, recurso este que teve de ser retirado dos resultados da própria Fazenda Malunga, período em que nenhum outro investimento na fazenda pôde ser feito, por razões financeiras.

Mas as casas são hoje, conforme informação dos entrevistados, uma opção que ajuda a minimizar a dificuldade de obtenção e retenção de mão-de-obra na empresa.

\subsubsection{Definição e Formalização do Planejamento Estratégico}

Conforme mencionado anteriormente, a empresa passou por uma fase de urgente necessidade de maior profissionalização, a fim de que pudesse se organizar para buscar um maior crescimento.

Para isso, a empresa contratou, há aproximadamente quatro anos, uma empresa de consultoria que lhe ajudou a formular seu Planejamento Estratégico, formalizando sua Missão, sua Visão em Valores, além de traçar seus objetivos e metas. Esse trabalho foi muito importante e ainda serve como parâmetro para decisões da empresa, cujas metas são revistas de seis em seis meses.

Conforme informado anteriormente, a missão, visão e valores da empresa são os seguintes: 
Missão: "Proporcionar qualidade de vida por meio da produção de alimentos orgânicos, educação ambiental e desenvolvimento de tecnologias limpas, respeitando o meioambiente, os colaboradores e consumidores, de forma competitiva."

Visão: "Consolidar-se como uma marca líder em produção de alimentos orgânicos, associada à qualidade de vida, por meio de uma gestão eficiente, utilizando-se de tecnologias limpas e equipes capacitadas como diferencial competitivo, comprometidos com a qualidade total e a satisfação dos consumidores e colaboradores".

Valores: qualidade de vida, respeito ao meio-ambiente e pessoas, responsabilidade social, honestidade, eficiência, competitividade.

\subsubsection{Dificuldades Relacionadas à Gestão Atualmente}

O Quadro 4.6 ilustra as principais dificuldades encontradas na gestão da Fazenda Malunga atualmente, conforme opinião dos entrevistados:

\section{Principais dificuldades encontradas atualmente}

- Encontrar e reter mão-de-obra

- Aumento da venda a supermercados X enfraquecimento da marca

- Alto custo com logística

- Dificuldade de acesso a crédito

\section{Possíveis soluções apontadas pelos entrevistados}

- Busca de parcerias

- Melhor capacitação de funcionários

Quadro 4.6 - Principais dificuldades encontradas em gestão atualmente

Fonte: Dados de pesquisa, elaborado pela autora, junho de 2009

A dificuldade na obtenção e retenção de mão-de-obra no meio rural, conforme opinião dos entrevistados, é uma situação preocupante no Brasil, impulsionada pelo êxodo rural, este estimulado pela busca de melhores condições de vida (nem sempre encontradas) nas cidades.

Outro dilema apontado pela empresa é o paradoxo entre o aumento de fornecimento a supermercados que, conforme já dito, compreende atualmente somente $30 \%$ do que os 
supermercados estariam dispostos a adquirir, em contradição com a possibilidade de enfraquecimento da marca, causado pela substituição da marca da empresa, por bandeiras dos clientes.

Além disso, um desafio difícil de ser enfrentado é o alto custo com logística, estando iminente a necessidade de investimento em mais um caminhão, conforme informação dos entrevistados.

A dificuldade de acesso a crédito é outro aspecto também já mencionado, que tem dificultado a gestão da empresa, desde sua concepção. 


\section{CONCLUSÕES E SUGESTÕES}

Esse capítulo se presta a apresentar as conclusões, propostas e sugestões, passíveis de vir à tona, a partir da leitura do trabalho apresentado.

Primeiramente, percebe-se que muitas foram as dificuldades enfrentadas pela empresa na condução do seu negócio, desde a sua concepção até os dias de hoje, sendo que alguns desses obstáculos são muito particulares ao Agronegócio, ou mesmo à produção de alimentos orgânicos.

Corroborando com a hipótese principal desse trabalho, foi possível observar que a empresa buscou inovar, muitas vezes, para superar dificuldades encontradas e, não só com esse fim, a empresa buscou inovar para buscar uma estratégia de crescimento sustentável que, conforme dito anteriormente, colocam-na, atualmente, no patamar de maior produtora de orgânicos do Distrito Federal.

Muitas das mudanças apresentadas podem ser consideradas práticas comuns em outros tipos de negócio como, por exemplo, a utilização da venda por internet e o oferecimento de ginástica laboral aos funcionários, mas definitivamente não são comuns ao universo do Agronegócio. Esse esforço inovativo é, portanto, muito importante e deve ser considerado estratégico para o tipo de negócio analisado.

Um aspecto a ser destacado é o processo de desenvolvimento da produção agrícola da empresa, marcado pela substituição de técnicas e tecnologias e pelo incremento de técnicas já utilizadas, podendo ser considerada hoje a área da empresa dotada de maior conhecimento e capacitação dos envolvidos.

A inclusão dos produtos minimamente processados e higienizados foi a mais importante inovação implementada pela empresa, pois permitiu maior agregação de valor aos produtos antes oferecidos, sendo uma diferenciação não comumente encontrada na agricultura convencional, como as saladas prontas, por exemplo.

No entanto, é importante enfatizar que a área de processamento pós-colheita da empresa, que pode ser sua maior fonte de renda requer a utilização de indicadores, objetivos e metas próprios a fim de que seja dada a devida importância estratégica para essa área da empresa. 
Outro aspecto importante é a forma como a empresa direcionou esforços para a comercialização de seus produtos, por meio da inovação com diversificação de canais de vendas e aperfeiçoamento de canais aparentemente já estabelecidos, como a venda a supermercados, em que foi introduzida a figura do promotor, com objetivos conscientemente definidos, voltados à maior e melhor comercialização dos produtos.

Apesar de mencionados ao longo do trabalho, não foi possível desenvolver, nessa pesquisa, todo o universo em torno das dificuldades atuais e cenários que se desenham a para o futuro da empresa.

Muita análise poderia ser feita a respeito desse momento particular em que se encontra a empresa, como por exemplo:

I. Esgotamento da capacidade produtiva da empresa, em que, conforme os entrevistados, traz como possibilidades o arrendamento de novas terras para desenvolvimento de produção própria e/ou estabelecimento de parcerias na produção a fim de suprir a demanda existente.

II. Aumento de vendas a supermercados versus possibilidade de enfraquecimento da marca Malunga: como as grandes redes de supermercado têm investido na substituição de bandeiras de fornecedores por bandeiras de marcas ligadas ao próprio supermercado, existe a possibilidade de que o consumidor não conheça a procedência do produto Malunga, o que pode dificultar o estabelecimento da marca, caso a empresa decida, algum dia, focar sua produção apenas em marca própria.

III. Dificuldade em encontrar/reter de mão-de-obra, particularidade inerente ao Agronegócio brasileiro.

Esse é um momento, portanto, em que a empresa deverá tomar algumas decisões e, quem sabe, inovar, a fim de buscar a solução de alguns de seus problemas ou dificuldades atuais.

Como possível política pública a ser implementada em favor do Agronegócio de Produtos Orgânicos, ou mesmo à produção rural de uma maneira geral, podem ser sugeridas ações de fomento à empregabilidade rural, ou seja, ao estímulo, baseado em algum incentivo governamental, ao aumento da disponibilidade de mão-de-obra voltada ao meio rural. 
Outra sugestão passível de ser implementada como política pública voltada ao fomento da produção rural do Distrito Federal, seria o oferecimento de crédito em condições compatíveis ao financiamento rural do Governo Federal, pelo Governo do Distrito Federal, às empresas rurais instaladas em áreas arrendadas do GDF, que não lhe permitem o enquadramento nas condições necessárias ao financiamento agrícola.

Por fim, é possível concluir, por meio da leitura e análise dos dados apresentados, que a trajetória da empresa Fazenda Malunga, desde sua concepção, há mais de 15 anos, até os dias de hoje, é marcada por muitos percalços, dificuldades, e superações, que demonstram que esta é uma empresa cujo histórico muito tem a ensinar a quem pretende adentrar o mundo dos negócios, mais particularmente, o Agronegócio Orgânico, cujo potencial de crescimento no Distrito Federal é animador. 


\section{REFERÊNCIAS}

BANCO NACIONAL DE DESENVOLVIMENTO ECONÔMICO E SOCIAL - BNDES. Agricultura orgânica: quando o passado é futuro. BNDES Setorial. Rio de Janeiro, n. 15, p. 3-34, mar. 2002. Disponível em: < http://www.bndes.gov.br > Acesso em 22 jan 2009.

ANDRADE, Maria Margarida de. Introdução à metodologia do trabalho científico: elaboração de trabalhos de graduação. São Paulo: Atlas, 2005.

BARROS, Aidil Jesus Paes de; LEHFELD, Neide Aparecida de Souza. Fundamentos de Metodologia: um guia para a iniciação científica. São Paulo: McGraw-Hill, 1986.

BESSANT, J. Challenges in innovation management. In: SOUSA, Jonilto Costa. Inovação no Contexto Organizacional: Fatores Facilitadores e Fatores Dificultadores. 186 f. Dissertação (Mestrado em Administração) - Universidade de Brasília - DF, 2006.

BESSANT, John, TIDD, Joe. Inovação e Empreendedorismo. Porto Alegre: Bookman, 2009.

BORGUINI, Renata Galhardo; TORRES, Elizabeth A. Ferraz da Silva. Alimentos Orgânicos: Qualidade Nutritiva e Segurança do Alimento. Núcleo de Estudos e Pesquisa em Alimentação. Disponível em: < http://www.unicamp.br/nepa>. Acesso em 12 abr 2009.

CRESTANA, Sílvio, SILVA, Renato C. Uma possível história da inovação e gestão do agronegócio no Brasil. In: ZUIN, Luiz Fernando Soares; QUEIROZ, Timóteo Ramos (Orgs.). Agronegócios - Gestão e Inovação. São Paulo: Saraiva, 2006.

DRUCKER, Peter F. Inovação e Espírito Empreendedor (entrepreneurship): prática e princípios. São Paulo: Pioneira Thomson Learning, 2005.

EMPRESA DE ASSISTÊNCIA TÉCNICA E EXTENSÃO RURAL DO DISTRITO FEDERAL - EMATER-DF. Pesquisa de Diagnóstico do Consumo de Produtos Orgânicos no Distrito Federal Análise Final. 2005. Disponível em <http://www.ematerdf.gov.br>. Acesso em 22 jan 2009.

FAZENDA MALUNGA: História, a Empresa. Disponível em < http://www.malunga.gov.br> Acesso em 22 jan 2009.

FIATES, Gabriela Gonçalves Silveira e FIATES, José Eduardo Azevedo. A inovação como estratégia em ambientes turbulentos. In: ANGELONI, Maria Terezinha e MUSSI, Clarissa Carneiro (org.). Estratégias: formulação, implementação e avaliação. $O$ desafio das organizações contemporâneas. São Paulo: Saraiva, 2008.

FONSECA, Maria Fernanda e WILKINSON, John. As oportunidades e os desafios da Agricultura Orgânica. In: LIMA, Dalmo M. de Albuquerque e WILKINSON, John (org.). Inovação nas tradições da agricultura familiar / Dalmo Marcelo de Albuquerque Lima, John Wilkinson et alli - Brasília: CNPQ / Paralelo 15, 2002. 
GIL, Antonio Carlos. Como elaborar projetos de pesquisa. São Paulo: Atlas, 1991.

HARVARD BUSINESS REVIEW. Inovação na prática: identificando novos mercados. Rio de Janeiro: Campus, 2002.

HISRICH, Robert D. Empreendedorismo / HISRICH, Robert D., PETERS, Michael P., SHEPHERD, Dean A. 7 ed. - Porto Alegre: Bookman, 2009.

INSTITUTO BRASILEIRO DE GEOGRAFIA E ESTATÍSTICA. Diretoria de Pesquisas Coordenação de Indústria. Questionário da Pesquisa de Inovação Tecnológica 2005. Disponível em < http://www.ibge.gov.br > Acesso em 26 mai 2009.

LOPES, Luciene de Andrade Bianchi; NANTES, José Flávio Diniz. Capacitação e empreendedorismo no setor rural. In: ZUIN, Luiz Fernando Soares; QUEIROZ, Timóteo Ramos (Orgs.). Agronegócios - Gestão e Inovação. São Paulo: Saraiva, 2006.

MAXIMIANO, Antonio Cesar Amaru. Teoria Geral da Administração: da revolução urbana à revolução digital. 6. Ed. - São Paulo: Atlas, 2006.

MINISTÉRIO DA AGRICULTURA, PECUÁRIA E ABASTECIMENTO - MAPA. Secretaria de Política Agrícola, Instituto Interamericano de Cooperação para a Agricultura. Cadeia Produtiva de Produtos Orgânicos. Brasília: IICA: MAPA/SPA, 2007. Disponível em < http://www.agricultura.gov.br > Acesso em 22 jan 2009.

MOTTA, Paulo Roberto. Transformação Organizacional: a teoria e a prática de inovar. Rio de Janeiro: Qualitymark Ed. 1998.

NANTES, José Flávio Diniz; LEONELLI, Fabiana Cunha Viana Leonelli. A estruturação da cadeia produtiva de vegetais minimamente processados. Revista da FAE. Curitiba, vol. 3 n. 3 , p. 61-80, set-dez 2000. Disponível em <http://www.fae.edu/publicações> Acesso em 06 mar 2009.

ORGANICSNET. Sociedade Nacional de Agricultura. O que é o produto orgânico? Disponível em: <http://www.organicsnet.com.br> Acesso em 12 abr 2009.

OLIVEIRA, Djalma de Pinho Rebouças de. Planejamento Estratégico: conceito, metodologia, práticas. São Paulo: 22. ed., 2. Reimpressão. Atlas, 2006.

PORTER, Michael E. Competição: estratégias competitivas essenciais. Rio de Janeiro: Elsevier, 1999.

SANTINI, Giuliana Aparecida; SOUZA, Roberta de Castro; QUEIROZ, Timóteo Ramos; SOUZA FILHO, Hildo Meirelles de. Conceitos de Inovação no Agronegócio. In: ZUIN, Luiz Fernando Soares; QUEIROZ, Timóteo Ramos (Orgs.). Agronegócios - Gestão e Inovação. São Paulo: Saraiva, 2006.

SCHUMPETER, Joseph. Teoria do Desenvolvimento Econômico. São Paulo: Nova Cultural, 1985. 
SERVIÇO DE APOIO ÀS MICRO E PEQUENAS EMPRESAS DO DISTRITO FEDERAL. Vitória da Persistência. Conhecer SEBRAE Agronegócios $\mathrm{n}^{\circ} 2$. Outubro de 2008. Disponível em: <http://www.biblioteca.sebrae.com.br> Acesso em 22 jan 2009.

SERVIÇO DE APOIO ÀS MICRO E PEQUENAS EMPRESAS DO DISTRITO FEDERAL. Histórias de Sucesso. Agronegócios: Agricultura Orgânica. Projeto Casos de Sucesso SEBRAE-DF 2007. Disponível em < http://www.casosdesucesso.sebrae.com.br> Acesso em 22 jan 2009.

SOARES, Nilda de Fátima Ferreira. Efeito da embalagem na conservação de produtos minimamente processados. In: Seminário Internacional de Pós-Colheita e Processamento Mínimo de Frutas e Hortaliças. Brasília: 2002. Disponível em: $<$ http://www.cnph.embrapa.br> Acesso em 22 jan 2009

TIDD, Joe; BESSANT, John; PAVITT, Keith. Gestão da Inovação. 3. ed. Porto Alegre: Bookman, 2008.

TIGRE, Paulo Bastos. Gestão da Inovação: a economia da tecnologia do Brasil. Rio de Janeiro: Elsevier, 2006.

VILCKAS, Mariângela; NANTES, José Flávio Diniz. Planejamento e agregação de valor nos empreendimentos rurais. In: ZUIN, Luiz Fernando Soares; QUEIROZ, Timóteo Ramos (Orgs.). Agronegócios - Gestão e Inovação. São Paulo: Saraiva, 2006.

YIN, Robert K. Estudo de Caso: planejamento e métodos. Trad. Daniel Grassi. 3. Ed. Porto Alegre: Bookman, 2005.

ZUIN, Luís Fernando Soares; ALLIPRANDINI, Dário Henrique. Gestão da inovação na produção agropecuária (GIPA). In: ZUIN, Luiz Fernando Soares; QUEIROZ, Timóteo Ramos (Orgs.). Agronegócios - Gestão e Inovação. São Paulo: Saraiva, 2006.

ZUIN, Luís Fernando Soares; QUEIROZ, Timóteo Ramos. Gestão e Inovação nos Agronegócios. In: ZUIN, Luís Fernando Soares; QUEIROZ, Timóteo Ramos (Orgs.). Agronegócios - Gestão e Inovação. São Paulo: Saraiva, 2006. 